\title{
A Comparison on Numerical Simulation Models for Vibrational Performances of the Wood Truss Joist Floor System
}

\author{
Yinlan Shen $\mathbb{D}^{\mathrm{D}},{ }^{1}$ Haibin Zhou $\mathbb{D D}^{2,3}$ Shuo Xue $\mathbb{D}^{4},{ }^{4}$ and Jinchuan Zhang $\mathbb{D}^{1}$ \\ ${ }^{1}$ Beijing University of Technology, Beijing 100124, China \\ ${ }^{2}$ Research Institute of Wood Industry, Chinese Academy of Forestry, Beijing 100091, China \\ ${ }^{3}$ National Engineering Research Center of Wood Industry, Beijing 102300, China \\ ${ }^{4}$ China State Railway Group Co., Ltd., Beijing 100844, China \\ Correspondence should be addressed to Haibin Zhou; zhouhb@caf.ac.cn
}

Received 24 February 2021; Revised 29 May 2021; Accepted 30 June 2021; Published 23 July 2021

Academic Editor: Pedro A. Costa

Copyright $\odot 2021$ Yinlan Shen et al. This is an open access article distributed under the Creative Commons Attribution License, which permits unrestricted use, distribution, and reproduction in any medium, provided the original work is properly cited.

\begin{abstract}
Wood truss joist floors are increasingly used to replace traditional solid timber joist floors in low-rise timber houses. An understanding of the vibration performance of wood truss joist floors is critical for the design and serviceability of the floors. It is difficult to model wood truss joist floors accurately because of the complicated boundary conditions and numerous sophisticated flexible connections. This paper discusses three simplified modeling methods for the wood truss joist floor system. The modeling results were validated by a series of static deflection tests and vibration modes and frequencies tests of a full-size floor. And predictive analysis of human-induced vibration of the floor was also conducted. The vibration characteristics of the wood truss joist floor were investigated. The examination of the applicability of these modeling methods was provided. The results indicate that the point loading deflection more easily affects the deflection of the adjacent joist. However, the deflection influence on other joists that are three spaces away is minimal. Walking on the wood truss joist floor produces steep vibration acceleration fluctuations at the floor center for a relatively long time period. The sheathing-to-joist connections and the metal plate connections of the joists have significant influences on the vibration response of the wood truss joist floor. The modeling method, which considers the flexible metal plate connections and flexible sheathing-to-joist connections, performs best for predicting the vibration performance of the floor.
\end{abstract}

\section{Introduction}

Lightweight joist wooden floors are widely used in residential and low-rise commercial buildings and include solid lumber joist floors, wood I-joist floors (stiffening ribs), and wood truss joist floors, as shown in Figure 1. The timber floor systems consist of several parallel joist members supporting the wood flooring or sheathing, which is connected to the joists in a semirigid manner. Solid lumber joist floors and wood I-joist floors were popular in the past in traditional light-frame timber construction. However, the use of solid lumber and I joist for floors has the disadvantages of potential low quality and a limitation of the floor span. What is worse is the improper web holes and flange notch made to allow the passage of electrical cables and ventilation systems; it easily leads to crack growth and even catastrophic damages in the joist $[1,2]$. Wood truss joist floors with truss joists connected by metal plates and sheathing connected to the joists by fasteners (nails or screws) are increasingly used to replace the traditional solid timber joist floors in low-rise residential houses because of the advantages of a large span, high strength, easy prefabrication, and convenient installation and access for service pipes and electrical cables. In addition, it is easier to ensure the high quality of wood truss joist floors, and more design freedom is provided for floors and roofs in domestic buildings.

An understanding of the human-induced vibration performance of wood truss joist floors is critical for the design and serviceability of the floors. The timber floor subjected to the footstep loads is supposed to generate a transient vibration response from each footstep declining to close to zero before the next footstep arrives [3]. Moreover, timber floors are more 


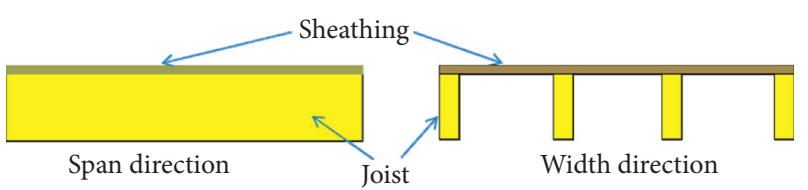

(a)

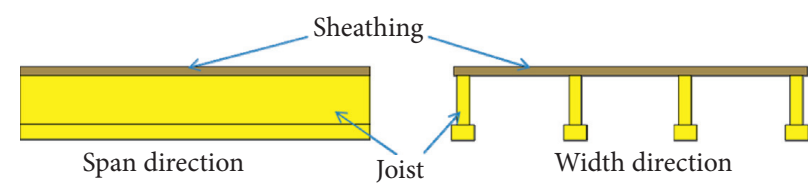

(b)

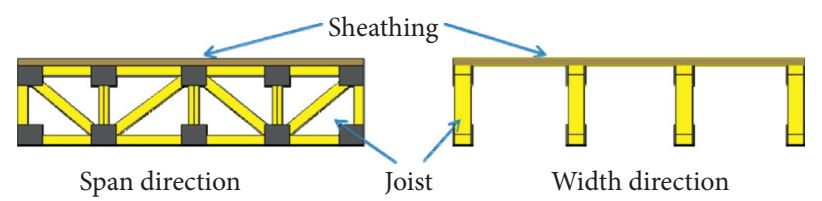

(c)

FIgURE 1: Classification of lightweight joist wooden floors. (a) Solid lumber joist floor. (b) Wood I-joist floor. (c) Wood truss joist floor.

susceptible to vibration than conventional steel or concrete floors due to their low mass. Numerous experimental studies have been conducted on assessing the vibration performance of different kinds of timber floors. Different authors proposed various design criteria for ensuring vibration serviceability of wood floors, listed in Table 1. Ohlsson [4] investigated the vibration performance of wood I-joist floors and proposed design criteria by limiting the fundamental frequency to values exceeding $8 \mathrm{~Hz}$, the point load deflection to $1.5 \mathrm{~mm}$, and the impulse velocity response to $100^{[f(1) \xi-1]}$. Smith and Chui [5] conducted experimental tests on solid lumber joist floors and suggested limiting the frequency-weighted root-mean-square acceleration to less than $0.45 \mathrm{~m} / \mathrm{s}^{2}$ and the fundamental frequency exceeding $8 \mathrm{~Hz}$. Johnson [6] and Dolan et al. [7] proposed a simple frequency-based design criterion without the consideration of other factors. The fundamental natural frequency of occupied and unoccupied floors is required to be greater than 14 and $15 \mathrm{~Hz}$, respectively. Patrick [8] pointed out that the only limitation of fundamental frequency of $15 \mathrm{~Hz}$ criterion is equivalent to a criterion limiting the deflection of a single joist under dead load to $1.4 \mathrm{~mm}$ (0.055 inches). It was similar to the deflection control of a wood floor. Eurocode 5 [9] uses a frequency-based standard of $8 \mathrm{~Hz}$ limit with deflection limitation and unit impulse velocity limit. The vibration performances of a broad range of timber floors were studied by experimental tests. Khokhar [10] analyzed the influence of bridging (lateral element) between solid lumber joists and found that this method was economical and effective for reducing vibration. Weckendorf et al. [11, 12] investigated the vibration performances of wood I-joist floors and open metal-web joist timber floors using laboratory tests. Zhang et al. $[13,14]$ presented an experimental study on the dynamic performance of open metal-web joist floors with strongbacks and evaluated the effects of the joist spacing, strongbacks, and ceiling on the mode shapes, damping performance, and unit point load deflection. Meanwhile, Zhang et al. $[15,16]$ investigated EC5 and British National Annex on the design of timber floor joists. Bernard [17] studied the effects of gypsum ceilings, battens, furring channels, posttensioning, blocking, and strapping within the lightweight engineered timber floor in control of perceptible vibration. Jarnero et al. $[18,19]$ also investigated the impacts of various boundary conditions and the addition of floor layers on vibration response of the floor.
Ding et al. [20] conducted a series of field tests on two-storey residential lightwood frame structures (including the fundamental frequency test, ball excitation dynamic vibration test, and pedestrian dynamic vibration test) and assessed the vibration comfort.

Owing to the difficulty of the analysis, present studies on the vibration of timber floors have largely relied on laboratory testing and there are fewer studies on numerical vibration analyses of lightweight wooden floors. $\mathrm{Hu}$ [21] conducted a numerical simulation of the dynamic behavior of ribbed plates with consideration of the rotary inertia and shear deformation. Weckendorf et al. [22] also performed a numerical study on the modal frequencies, mode shapes, and static point load deformation of an I-joist timber flooring system. Glisovic and Stevanovic [23] developed the numerical models of the solid lumber joist floor system to investigate the parameter effect on the vibration performances (joist spacing, depth, sheathing thickness, nail spacing, bridging, and support condition).

However, in the respect of wood truss joist floors, the static and dynamic performances related to the vibration serviceability have not been clarified to date. Numerical simulation combined with laboratory studies improves our understanding of the complexities of the vibration response of wood truss joist floor systems. The vibration performances include the fundamental frequency, vibration modes, point load deflection, and transient vibration response caused by the occupants' activities. In this study, three modeling methods of the wood truss joist floor were developed and the numerical modeling results were verified with a series of static test results, vibration frequencies, and modes of a full-size floor. Subsequently, the models were also used to predict the floor vibration response induced by walking. An examination of the applicability of the modeling methods was discussed. This paper is intended to contribute to the simple and feasible numerical modeling methods of the wood truss joist floor in aspect of vibration performance for a future vibration serviceability study.

\section{Overview of the Wood Truss Joist Floor}

The wood truss joist floor system consisted of 15 truss joists with a spacing of $400 \mathrm{~mm}$, oriented strand board (OSB) panels $(15 \mathrm{~mm})$ covering the joists, and laminated veneer lumber 
TABLE 1: Design criteria for ensuring the vibration serviceability of wood floors.

\begin{tabular}{|c|c|c|}
\hline Authors & Floor type & Details of design criterion \\
\hline Ohlsson [4] & $\begin{array}{l}\text { Wood I-joist } \\
\text { floor }\end{array}$ & $\begin{array}{c}\text { The fundamental frequency } F 1 \geq 8 \mathrm{~Hz} \text {; the point load deflection } a \leq 1.5 \mathrm{~mm} \text {; the impulse velocity } \\
\text { response } v \leq 100^{[f(1) \xi-1]}\end{array}$ \\
\hline Smith and Chui [5] & $\begin{array}{l}\text { Wood solid joist } \\
\text { floor }\end{array}$ & $\begin{array}{l}\text { The fundamental frequency } F 1 \geq 8 \mathrm{~Hz} \text {; the frequency-weighted root-mean-square acceleration } \\
\qquad a_{\mathrm{rms}} \leq 0.45 \mathrm{~m} / \mathrm{s}^{2}\end{array}$ \\
\hline Johnson [6] & $\begin{array}{l}\text { Solid sawn joist } \\
\text { floor }\end{array}$ & The fundamental frequency $F 1 \geq 15 \mathrm{~Hz}$ \\
\hline Dolan et al. [7] & $\begin{array}{l}\text { Wood solid joist } \\
\text { floor }\end{array}$ & $\begin{array}{l}\text { The fundamental frequency } F 1 \geq 14 \mathrm{~Hz} \text { for occupied floors; the fundamental frequency } F 1 \geq 15 \mathrm{~Hz} \\
\text { for unoccupied floors }\end{array}$ \\
\hline Eurocode 5 [9] & Wood joist floor & $\begin{array}{l}\text { The floor with the fundamental frequency lower than } 8 \mathrm{~Hz} \text { requires additional checks; in common } \\
\text { cases, the fundamental frequency of the floor is required to be great than } 8 \mathrm{~Hz} \text {; and the maximum } \\
\text { deflection } w / F \leq a \text {; and the unit impulse velocity } v \leq \beta^{[f(1) \xi-1]}\end{array}$ \\
\hline
\end{tabular}

(LVL) plates as the rim board for the whole floor, which was connected to the ends of the joists, shown in Figure 2. The floor system $(6.114 \mathrm{~m}$ long and $5.689 \mathrm{~m}$ wide) was attached to walls with $1.85 \mathrm{~m}$ height. The walls consisted of sawn lumber and were sheathed with OSB panels. The OSB subfloor was connected to the top chords of the wood trusses using $4 \times 50 \mathrm{~mm}$ screws of $150 \mathrm{~mm}$ oc around the perimeter and $300 \mathrm{~mm}$ oc in the field, shown in Figure 3(a). The major direction of the OSB sheathing in-plane is placed perpendicular to the joist. The mean density of the OSB sheathing was measured as $650 \mathrm{~kg} / \mathrm{m}^{3}$. The mean major elastic modulus of the OSB sheathing has been determined as $4080 \mathrm{MPa}$ with the minor elastic modulus of $2080 \mathrm{MPa}$. Self-drilling screws with the length of $70 \mathrm{~mm}$ and the diameter of $4 \mathrm{~mm}$ were used to fasten the edge joists to the walls with a distance of $250 \mathrm{~mm}$ (Figure 3(b)). The LVL rim board with a thickness of $38 \mathrm{~mm}$ and a height of $440 \mathrm{~mm}$ was connected to each joist with the same self-drilling screws. The mean elastic modulus parallel to the grain of the LVL board has been determined as $13000 \mathrm{MPa}$ and $1000 \mathrm{MPa}$ for other directions. The mean density of the LVL board was measured as $600 \mathrm{~kg} / \mathrm{m}^{3}$. Both the ends of the joists were fastened to the walls with the same two self-drilling screws (Figure 3(c)).

Dimensional lumbers of spruce-pine-fir (SPF) $(38 \mathrm{~mm} \times 89 \mathrm{~mm})$ used for the flange and web members compose the herringbone truss joist with an overall joist depth of $440 \mathrm{~mm}$, illustrated in Figure 4. The mean elastic modulus parallel to the grain EL for dimensional lumbers chords had been determined as $8700 \mathrm{~N} / \mathrm{mm}^{2}$, with the elastic modulus for the radial direction ER of $600 \mathrm{~N} / \mathrm{mm}^{2}$ and for the chord direction ET of $400 \mathrm{~N} / \mathrm{mm}^{2}$. The mean density of dimensional lumbers, $\rho$, was determined as $560 \mathrm{~kg} / \mathrm{m}^{3}$. The flange and web members were connected with metal plates produced by MiTek Ltd. The metal plates were made using thin steel plates of $1 \mathrm{~mm}$ thickness with zinc coat and teeth of $8.4 \mathrm{~mm}$ height. The mean yield strength of the metal plates has been measured as $271.95 \mathrm{MPa}$, and the tension strength has been measured as $341.32 \mathrm{MPa}$. The mean elastic modulus of the steel plate is assessed as $203 \mathrm{GPa}$.

\section{Numerical Simulation Methods}

Park et al. [24] presented a finite element model for lightweight steel floors ( $\mathrm{C}$ or Z light-gauge steel joists were welded to the beams); a rigid rink was used to deal with the differences in the centroid of the beam, joist, and flooring material. Zhang et al. [25] proposed a damped plate-oscillator model to obtain the dynamic properties of coupled flooroccupant systems, and the model was verified using laboratory tests of the full-size lightweight cold-formed steel floor. Setareh [26] conducted a comparison of modal testing and computer analysis and sensitivity studies on the dynamic responses of a long steel truss cantilevered floor. However, flexible connections in wood truss joist floors differ significantly from the rigid welded connections in lightweight steel floors or steel truss floors. Barron and Kim [27] added nonlinear springs to characterize the rotation of the heel joint of the metal plate-connected wood roof trusses in the Sap2000 software. Xu [28] determined that each metal plate connection exhibited axial deformation, shear deformation, and rotation deformation and suggested the use of three spring elements to quantify the axial, shear, and rotation behaviors. However, for a wood truss joist floor system, the trade-off between model complexity and computational effort should be considered. Detailed models that consider the behavior of the connection between each web member and the chord member with different angles in three directions are computationally complex, especially for multiangle and multimember intersections in a wood truss floor system.

3.1. Model Description. In this study, the finite element software Ansys was used for the numerical analysis of the wood truss joist floor. Three simplified methods were proposed, in which the connections were simplified as follows: (i) pinned connections for metal plate connections and rigid connections for sheathing-to-joist connections (method I); (ii) orthogonal springs to characterize the inplane shear and tension or compression performances of the 


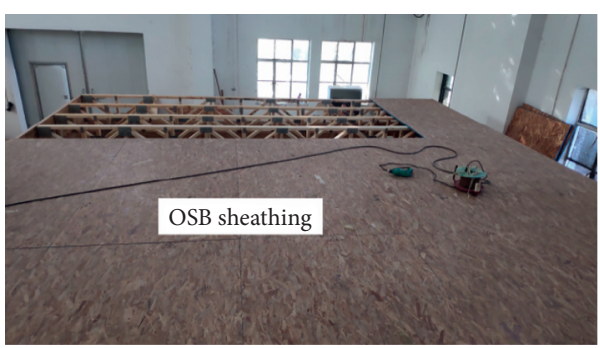

(a)

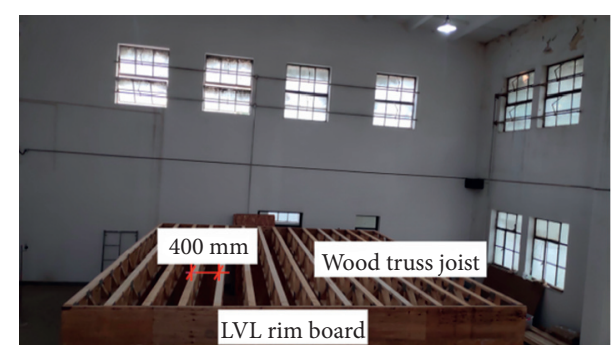

(b)

FIgURE 2: Wood truss joist floor system. (a) OSB subfloor. (b) 15 truss joists.

metal plate connections and rigid connection for sheathingto-joist connections (method II); and (iii) orthogonal springs to characterize the in-plane shear and tension or compression performances of the metal plate connections and springs to quantify the in-plane shear deformation for orthogonal direction between the fasteners and the sheathing (method III). The simplification of the fixed support between the edge joists and the walls and the simply supported connection between the other joists and the walls were assumed in the numerical analysis.

It should be mentioned that the connections of the wood floor commonly exhibit recoverable linear-elastic deformation during floor vibration. The orthogonal springs were used to quantify the in-plane elastic shear deformation for orthogonal direction between the fasteners $(4 \times 50 \mathrm{~mm}$ screws $)$ and the OSB sheathing, illustrated in Figure 5. Based on different definitions of the yield point from load-displacement curves used in different countries [29-34] and numerous actual curves for timber connections, the initial periods defined between $0 \%$ and $40 \%$ of the maximum load of the load-displacement curves of timber connections are conservatively accepted as linear-elastic periods. The curve from $40 \%$ of the maximum load to peak load obviously experiences nonlinear plastic deformation. The average envelope curves for the load-slip test of a single-shear screwed $15 \mathrm{~mm}$ OSB panel joint were quantified by multilinear curves, shown in Figure 6. The multilinear curves are determined using the point at $40 \%$ of the maximum load and the points of obvious slope variation and the peak load of the curves. The numerical vibration analysis related to floor serviceability indicated that the deformations of the timber connections are in the elastic phase between $0 \%$ and $40 \%$ of the maximum load of the load-displacement curves. Thus, the linear-elastic stiffness parameters of screwed connections (Disp 1 and Load 1) are defined as the displacement and load corresponding to $40 \%$ of the maximum load of the curves, listed in Table 2.

For metal plate connections in the model, the connection stiffness of each web member with various angles to chords cannot be quantified, respectively. In order to simply consider the in-plane shear and tension or compression performances of metal plate connections, it was assumed that the multiweb members produce a composite force at a reference node (composite force node). No matter what kind of joint, the elastic stiffness of the connection between composite force node for multiweb members and the continuous chord is assumed to the same. The composite force node for multiweb members is connected to the continuous chords with orthogonal zero-length nonlinear springs, which enables us to quantify the relationship between the component force and the deformation in the directions of the major axis (shear) and minor axis (tension) of the connections while neglecting the effect of the rotation stiffness, taking three web members connecting to the chord as an example, shown in Figure 7.

For the determination of shear and tension stiffness of metal plate connections in the model, the experimental results of single web member connected to the chord with different angles were only taken as the reference. However, the curves of specimens demonstrated discreteness with stiffness and strength [35-38]. The interaction of multiweb members connecting to the chord differs the situation of the single web member connecting to the chord. We use the experimental results of the third-point bending loading test for single wood truss to calibrate the elastic stiffness of metal plate connections in the model. As long as the load deformation of a wood truss joist was obtained from an experiment, the calibration of the shear and tension stiffness of the metal plate connections could be easily performed by modeling the static response of the single wood truss test. This ensures the accuracy of numerical modeling in the aspect of the component level and reduces the dispersion of numerical results. When vertical compression behavior occurs, the installment gap of the connection is eliminated under the assumption of infinite compression stiffness of the connection; at this time, the vertical compression was only affected by the stiffness of the members.

\subsection{Model Verification Based on the Wood Truss Joist Test.} When designing wood floors, a commonly used limit of the maximum deflection produced by a uniformly distributed live load of $1.9 \mathrm{kPa}$ is less than $1 / 360$ of the span for floors with sawn lumber joists [39]. Thus, the midspan deflection of a single wood truss under a total vertical load of $3.34 \mathrm{kN}$ (equivalent to a uniformly distributed load of $1.9 \mathrm{kPa}$ ) was evaluated in a third-point bending loading test. Based on the standards JGJ/T265-2012 [40] and ASTM E73-13 [41], the timber truss joist was loaded synchronously at one-third points of the upper chord using the special $\mathrm{H}$ steel beam and hydraulic synchronous loading system, illustrated in Figure 8. 


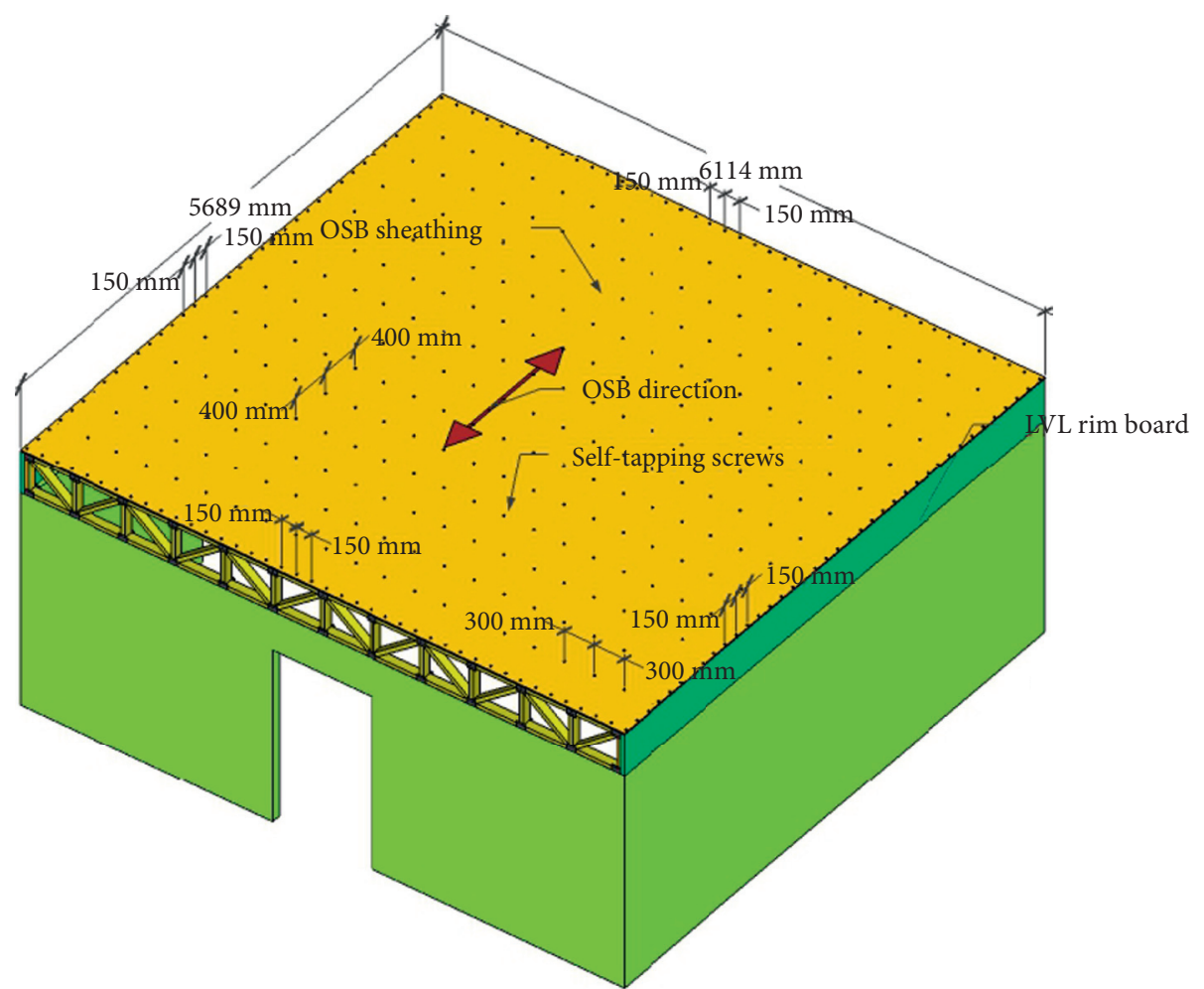

(a)

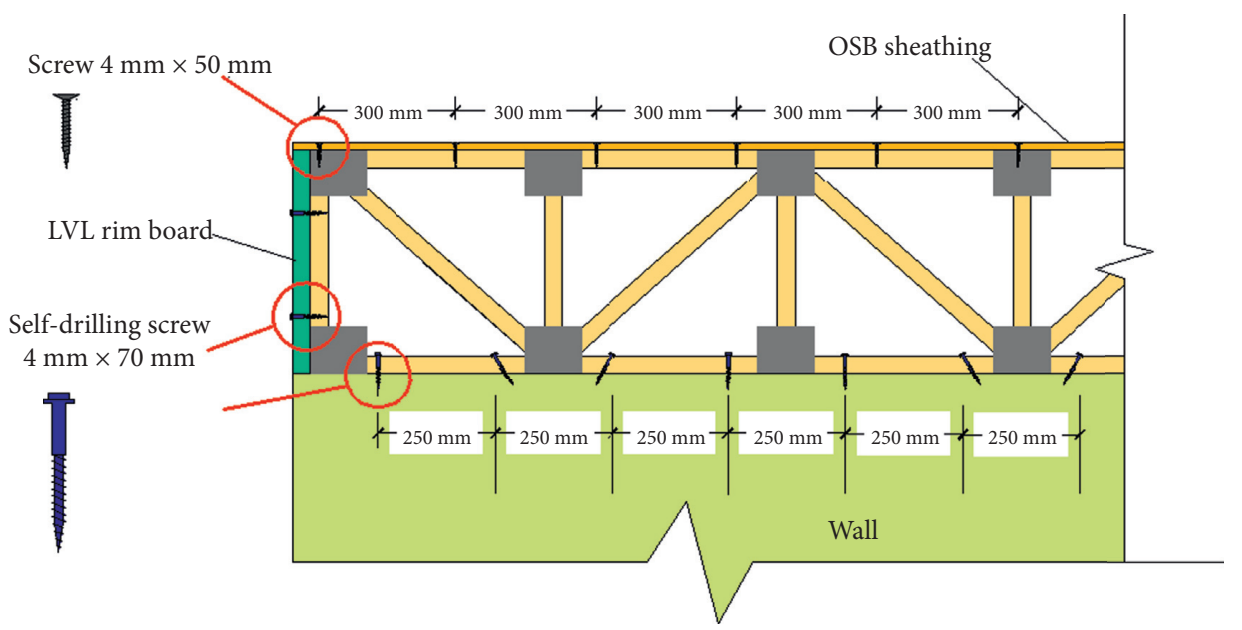

(b)

Figure 3: Continued. 


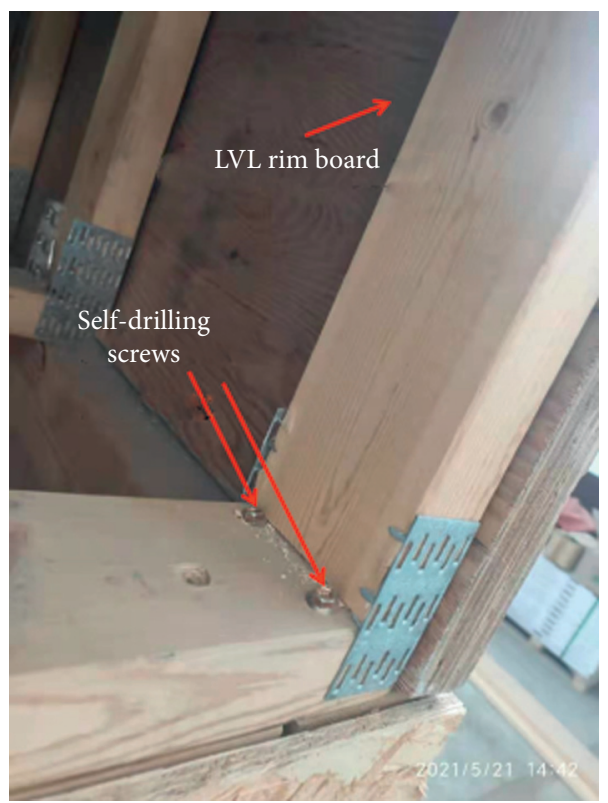

(c)

Figure 3: Details of wood truss joist floor system. (a) Dimensions of the floor. (b) Connections between the edge joist and the wall. (c) Connections between both the ends of the joists and the wall.

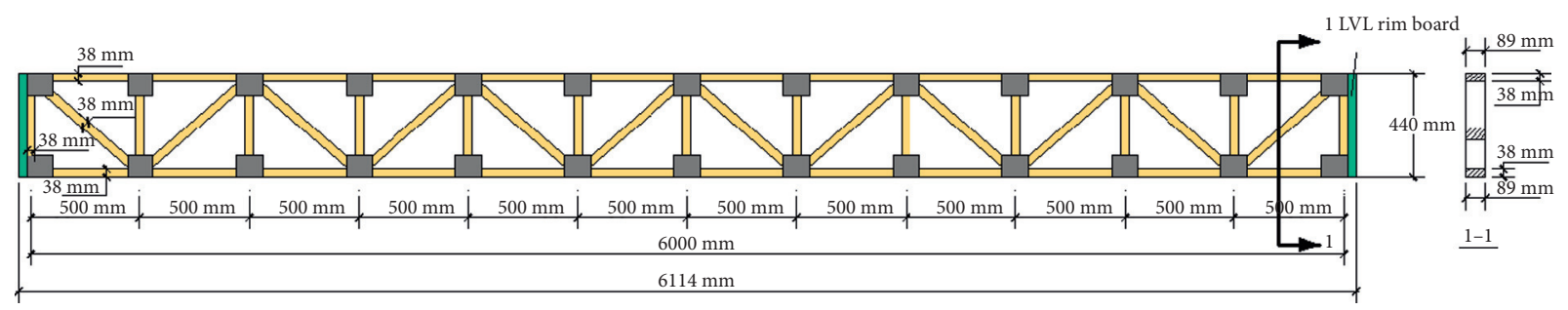

FIGURE 4: Details of a single truss joist.

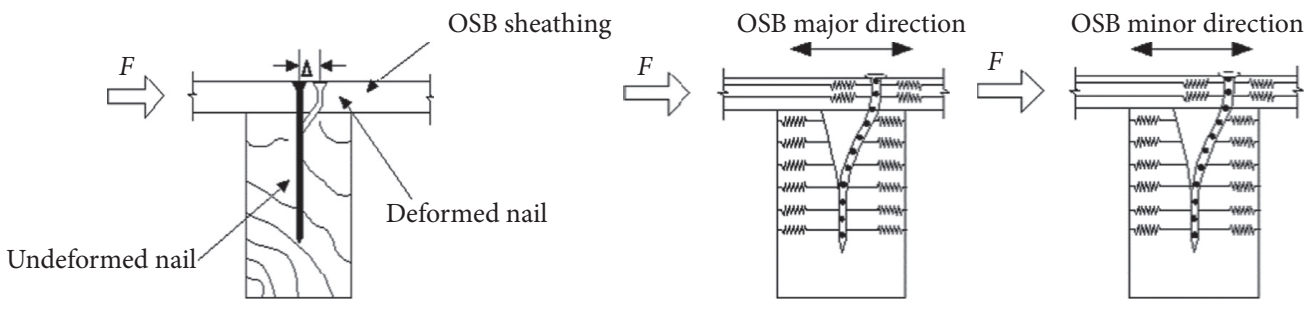

FIGURE 5: Spring models for the nailed/screwed connections.

Both the ends of the wood truss were supported by steel blocks to create simple supports, and an out-of-plane supporting system was used for both the sides near the three equal points of the truss to prevent out-of-plane overturning, as shown in Figure 9. There was a small gap with no contact between the out-of-plane support and the truss to prevent interference with the vertical deflection. The load increase is controlled according to each loading level of $0.25 \mathrm{kN}$ with the maximum load of up to $3 \mathrm{kN}$ and the loading time interval of 1 minute. For floor serviceability issue, the load of $3 \mathrm{kN}$ for the wood truss joist is enough. The displacement sensors (CDP-50) are placed to measure the displacement of both ends of the joist ( $P 1$ and $P 2$ ) and the displacement of midspan of the joist $(P 3)$. The average experimental deformations at the midspan of three trusses are shown in Figure 10. For the test data, the deformation of the midspan at the bottom of the truss exhibited a nearly linear increase up to less than $6 \mathrm{~mm}$ with an increase in the load from 0 to $3 \mathrm{kN}$. The maximum deflection of the designed wood truss joist produced by a uniformly distributed live load of $1.9 \mathrm{kPa}$ is about $1 / 1105$ of the span, which is far less than the design limit (1/360), to keep in the elastic status.

In numerical modeling, the material parameters of the wood-engineered products were tested and are provided in 


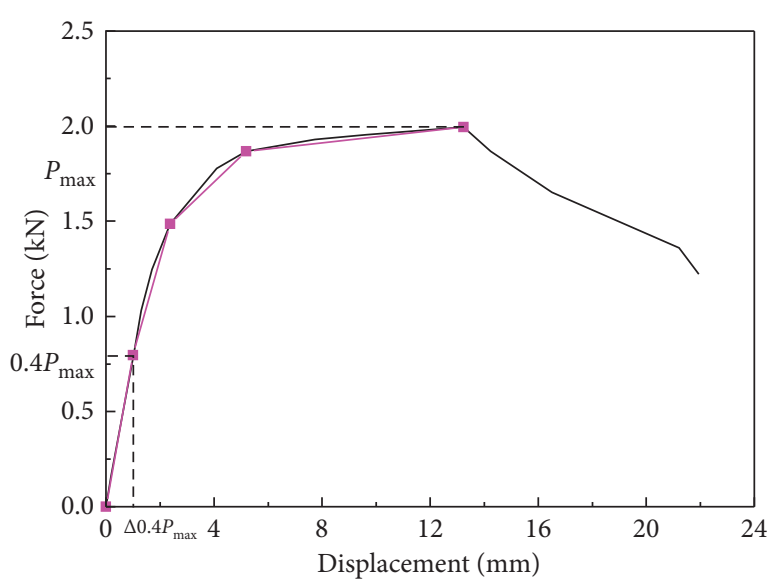

Single-shear curve

— Load-slip curve-minor axis

- Fitting point

(a)

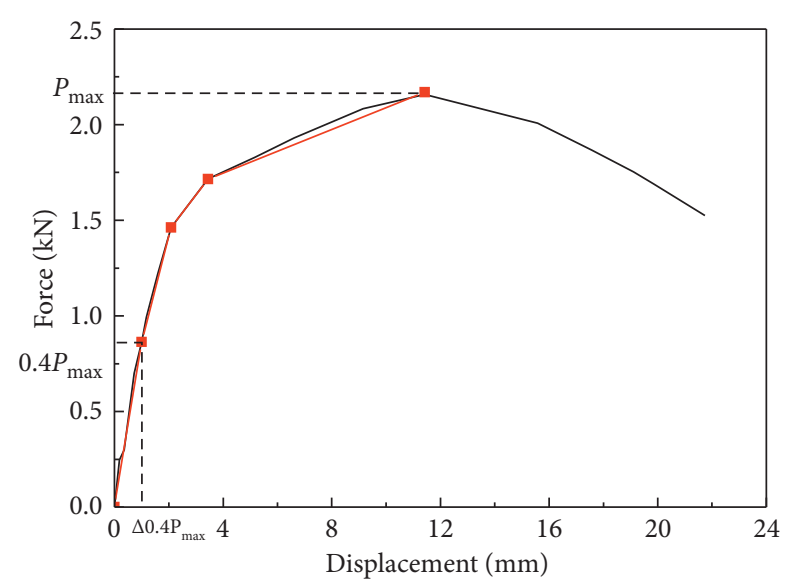

Single-shear curve

— Load-slip curve-major axis

$\rightarrow-$ Fitting point

(b)

FIGURE 6: Load-slip curves of single-shear screwed OSB panel joint: minor direction (a) and major direction (b).

TABLE 2: Sheathing-to-joist connection parameters.

\begin{tabular}{lcccc}
\hline Type of connections & Directions & Disp 1 (m) & Load 1 (N) & Stiffness $(\mathrm{kN} / \mathrm{m})$ \\
\hline Single-shear screwed & OSB minor axis (shear) & 0.001 & 807 & 807 \\
OSB panel connections & OSB major axis (shear) & 0.001 & 863 & 863 \\
\hline
\end{tabular}

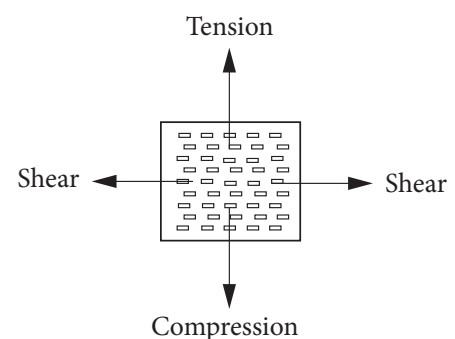

(a)

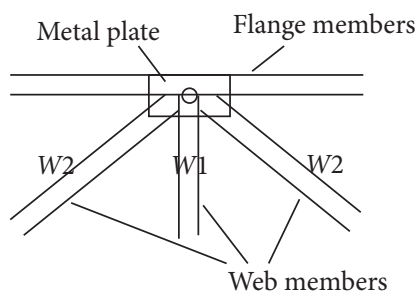

(b)

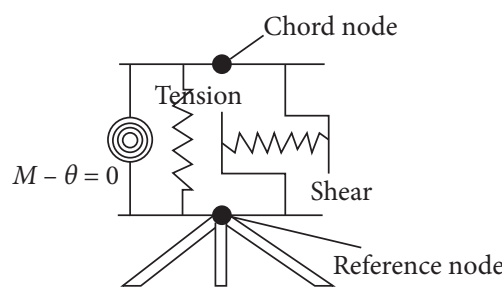

(c)

FIgURE 7: Spring models for the metal plate connections.

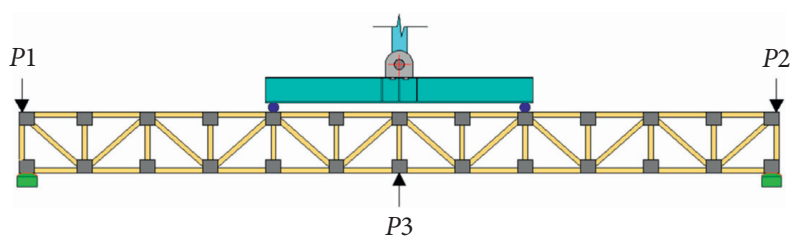

Figure 8: Loading system.

Table 3. The shear and tension stiffness of metal plate connections is calibrated to fit the experimental load deformation of single wood truss joist. Table 4 presents the calibrated linear-elastic parameters for metal plate connections. The numerical deformation for modeling the static bending test of single wood truss fits the experimental results well, shown in Figure 10. The numerical increasing trend of midspan deformation is close to the tested results. That is to say, the stiffness of the numerical model of the wood truss joist is close to that of the tested actual wood truss joist. Meanwhile, the modeling peak displacement is also close to the measured data. The modeling result considering flexible metal plate connections $(5.56 \mathrm{~mm})$ was slightly larger compared to the tested value $(5.43 \mathrm{~mm})$ subjected to $3 \mathrm{kN}$. The reason for the error may be the connection gap existing of the fabricated wood truss joist floor and discreteness and variability of the natural wood materials including finger joints of flange members and the scarring defect of the dimension wood.

\section{Vibration Performance Analysis of the Floor}

4.1. Experimental and Numerical Analysis of Static Deflection. The approach of limiting the maximum deflection of floors under a concentrated live load has been widely used because such a limitation relates more directly to floors subjected to 


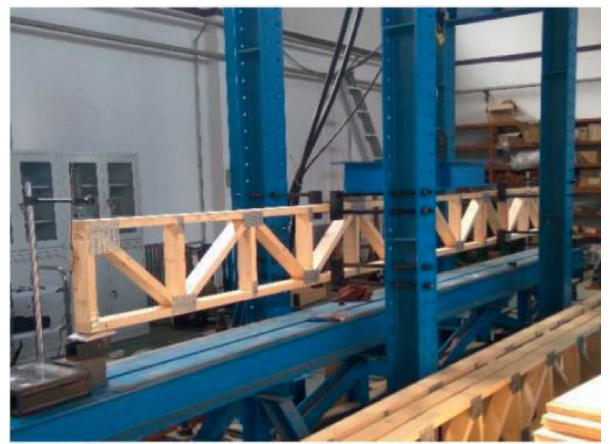

Figure 9: Single wood truss in the three-point loading test.

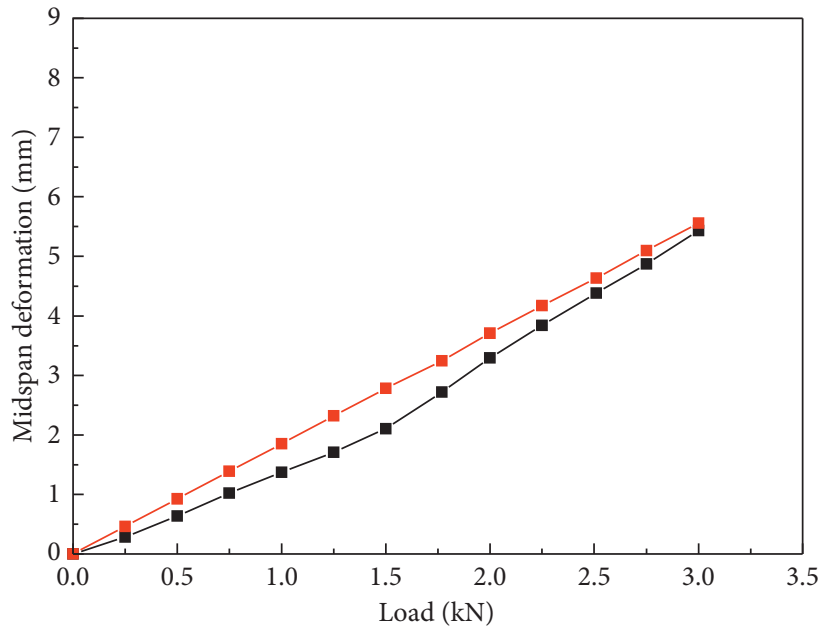

Single wood truss joist

- - Experimental result

- - Flexible metal plate connection modeling result

Figure 10: Numerical modeling and test results for a single wood truss joist.

TABLE 3: Model parameters of the engineered wood materials.

\begin{tabular}{lccc}
\hline & SPF & OSB & LVL \\
\hline Section & $38 \mathrm{~mm} \times 89 \mathrm{~mm}$ & $15 \mathrm{~mm}$ thickness & $38 \mathrm{~mm}$ thickness \\
EL $(\mathrm{MPa})$ & 8700 & 4280 & 13000 \\
ER $(\mathrm{MPa})$ & 660 & 2080 & 1000 \\
ET $(\mathrm{MPa})$ & 400 & 2080 & 1000 \\
GLR $(\mathrm{MPa})$ & 500 & 1000 & 700 \\
GLT $(\mathrm{MPa})$ & 500 & 50 & 700 \\
GRT $(\mathrm{MPa})$ & 53 & 57 & 60 \\
$\mu$ LR & 0.43 & 0.15 & 0.335 \\
$\mu$ LT & 0.47 & 0.3 & 0.03 \\
$\mu$ RT & 0.2 & 0.15 & 0.466 \\
$\rho\left(\mathrm{kg} / \mathrm{m}^{3}\right)$ & 560 & 650 & 600 \\
\hline
\end{tabular}

TABle 4: Connection parameters for metal plate connections.

\begin{tabular}{lcccc}
\hline Type of connections & Directions & Disp 1 $(\mathrm{m})$ & Load 1 $(\mathrm{N})$ & Stiffness $(\mathrm{kN} / \mathrm{m})$ \\
\hline \multirow{2}{*}{ Metal plate connections } & Major axis (shear) & 0.000158 & 5500 & 34.80 \\
& Minor axis (tension) & 0.000158 & 9000 & 56.96 \\
\hline
\end{tabular}


the force exerted by the footfall of people. The measurement results were used to assess the performance of the three numerical modeling methods.

4.1.1. Methods for Static Deflection Tests of the Floor. The floor was tested to measure the deformation at the midspan of the joists under a concentrated load of $1 \mathrm{kN}$. We placed $100 \mathrm{~kg}$ iron rollers at different points on the sheathing, and different places at the bottom of the joists were selected to monitor the deflection response and determine the vibration mechanics and integration performance of the floor. The loading points were located on every third joist at the center of the joists and were numbered from $W 1$ at the bottom to $W 5$ at the top (Figure 11(a)). Meanwhile, other loading points were distributed at the same distance in the middle of the joist and were numbered from $L 1$ on the right to $L 5$ on the left (Figure 11(a)). Displacement transducers with a resolution of $0.001 \mathrm{~mm}$ (ID-C ABSOLUTE Digimatic543-490B, Mitutoyo, Japan) were installed by attaching to the steel hangers at the monitoring points at the bottom of the trusses. The monitoring points were distributed as follows: at the center of the second joist $(P 1)$, the fifth joist $(P 2)$, the seventh joist $(P 3)$, the middle joist (P4), the ninth joist (P5), the eleventh joist (P6), and the fourteenth joist (P7), as illustrated in Figure 11(b).

4.1.2. Comparison of the Measured and Modeled Static Deformations. Figure 12 shows the deflection of the floor at the monitoring points ( $P 1$ to $P 7$ ) when a concentrated load of $1 \mathrm{kN}$ was applied at $W 1, W 2, W 3, W 4$, and $W 5$ successively in the experiment; the comparison between modeling results and experimental results is illustrated in Figure 13. The red lines indicate the results of method I, the blue lines show the results of method II, and the magenta lines show the results of method III (the same applies to subsequent figures). It was found that almost symmetrical deflection corresponds to the locations of the loading points on the middle joist. Since the elastic stiffness of the metal plate connections was not considered in method I, the deformation was significantly underestimated in this method. In contrast, the modeling results of methods II/III were in good agreement with the experimental results and exhibited a similar trend.

When the load was applied to $W 1$, the maximum experimental deflection $(0.9 \mathrm{~mm})$ occurred at $P 7$, which was located under the loading point; the minimal deflection near $0 \mathrm{~mm}$ was observed at $P 6$, which was located three joists away from $W 1$ (Figure 12). The modeling results showed that method I provided the lowest value of $0.62 \mathrm{~mm}$ in contrast to the experimental result of $0.9 \mathrm{~mm}$ at $P 7$, and significant differences in the values were also observed at the other monitoring points ( $P 1$ to $P 6)$. Method II provided a slightly lower value at $P 7(0.88 \mathrm{~mm})$ than the experimental result $(0.97 \mathrm{~mm})$, and method III yielded a slightly higher value $(1.1 \mathrm{~mm})$. When the load was symmetrically applied to $W 5$, a similar trend of the model results compared to the experimental results was found.

When the load was applied to $W 2$, the maximum experimental deflection $(1-1.12 \mathrm{~mm})$ occurred at $P 6$, which was under the loading point $W 2$. The deflection was small $(0.1 \mathrm{~mm})$ at $P 5$, which was two joists away from the loading point $W 2$; the influence on the other monitoring points was negligible. Method II provided a slight underestimation of $0.98 \mathrm{~mm}$ at $P 6$ and $P 2$. Method III provided a value of $1.15 \mathrm{~mm}$. Method I resulted in a much lower value $(0.7 \mathrm{~mm})$ than the experimental result. A similar trend also occurs at the symmetrically loading point of $W 4$.

When the load was applied to $W 3$, the maximum experimental deflection occurred at $P 4(1.05 \mathrm{~mm})$, which was under the loading point $W 3$; the deflection was between $0.43 \mathrm{~mm}$ and $0.56 \mathrm{~mm}$ at $P 3$ and $P 5$, which were one joist away from the loading point. The influence on the points $P 2 / P 6$ and $P 1 / P 7$, which were more than three joists away, was negligible (Figure 12). For the modeling aspect, a similar trend was observed for methods II/III; the largest deflection obtained from method II was $0.98 \mathrm{~mm}$ (1.14 mm for method III) at P4 (Figure 13). However, the assumption of pin connection in method I results in a significant underestimation of the deformation of $0.7 \mathrm{~mm}$. At the adjacent joists, method III $(0.42 \mathrm{~mm})$ provided results that were closest to those of the experiment at $P 3$ and $P 5$ $(0.43 \mathrm{~mm}-0.56 \mathrm{~mm})$, followed by method II $(0.37 \mathrm{~mm})$ and method I $(0.27 \mathrm{~mm})$. In general, under a static concentrated load of $1 \mathrm{kN}$, the deflection at the midspan of the joist reached the maximum value of about $1 \mathrm{~mm}$, which affected the deflection of the adjacent joist. The influence on other joists that were three spaces away was minimal at about $0.1 \mathrm{~mm}$, and the effect on the joists at the further distance was negligible.

Figure 14 shows the experimental and model results of the deflection at $P 1$ to $P 7$ when a concentrated load of $1 \mathrm{kN}$ was applied to $L 1$ and $L 5$ successively. Figure 15 shows the respective results for applying a load to $L 2$ and $L 4$ successively. The results showed a good agreement between the experimental and model results. When the load was applied to $L 1$ or $L 5$, the measured deflection at $P 4$ in the middle of the joist was about $0.3 \mathrm{~mm}$ and the deflection at the adjacent joists was less $(0.15-0.25 \mathrm{~mm})$. Method III provided a value that was closest to the experimental results at $P 4(0.27 \mathrm{~mm})$, followed by method II $(0.23 \mathrm{~mm})$ and method I $(0.19 \mathrm{~mm})$ (Figure 14). When the load was applied to $L 2$ or $L 4$, the measured deflection at $P 4$ was $0.65-0.7 \mathrm{~mm}$; the model results show close values of $0.79 \mathrm{~mm}$ for method III and $0.67 \mathrm{~mm}$ for method II at P4. However, method I underestimated the values, with relatively high errors (Figure 15).

Although the distances between the loading points $L 1$, $W 1, L 5$, and $W 5$ and the monitoring point $P 4$ at the center are the same, loading on $L 1$ and $L 5$ resulted in a larger deflection at $P 4$ than loading on $W 1$ and $W 5$. The same trend was observed for $L 2, L 4, W 2$, and $W 4$. The reason is that, under a static concentrated load of $1 \mathrm{kN}$, the loading load is directly transferred to the same loading joist and causes the deflection, whereas in perpendicular to the joist direction, the loading force applied to the adjacent joists significantly decreases with the increasing distance from the loading point, and the influence on the joists that were three spaces away was minimal. The metal plate connection of the joists provides linear-elastic stiffness, resulting in a large recoverable deflection because the connection is not rigid. In addition, the nailed connection between the sheathing and 


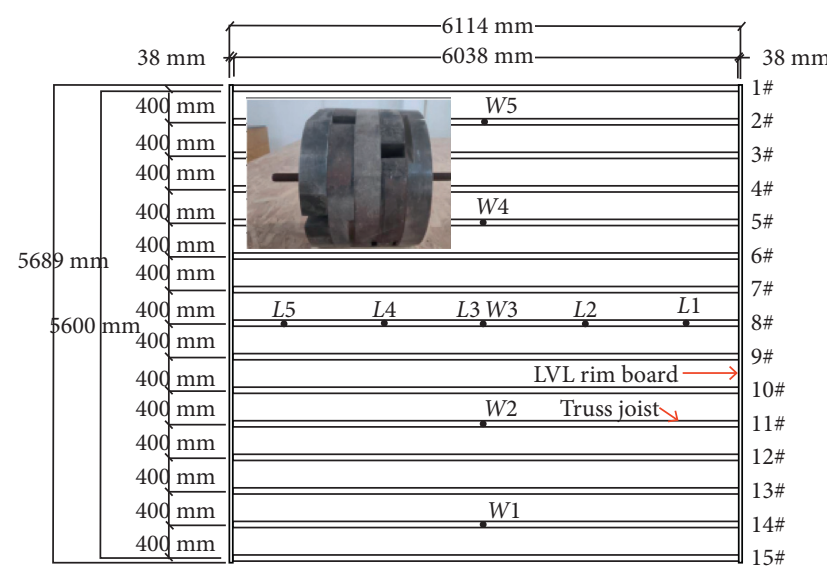

(a)

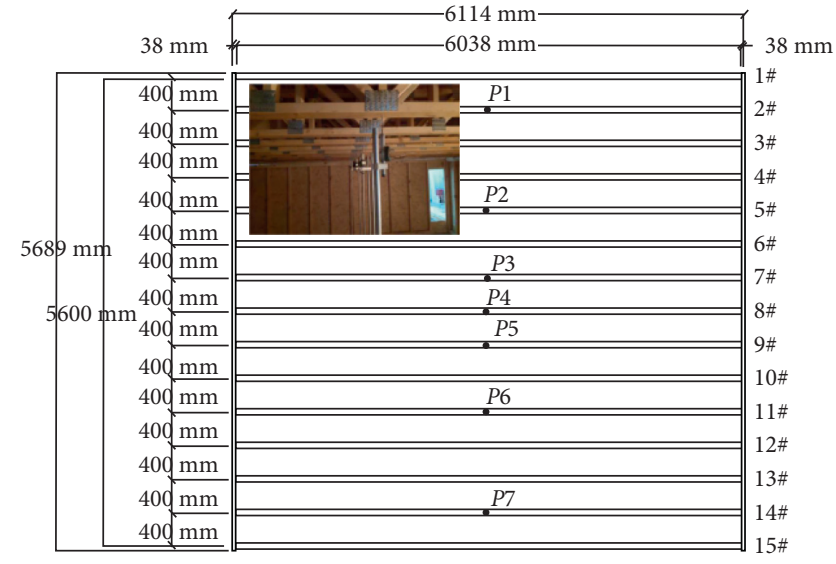

(b)

FIGURE 11: Distributions of the loading points (a) and monitoring points (b).

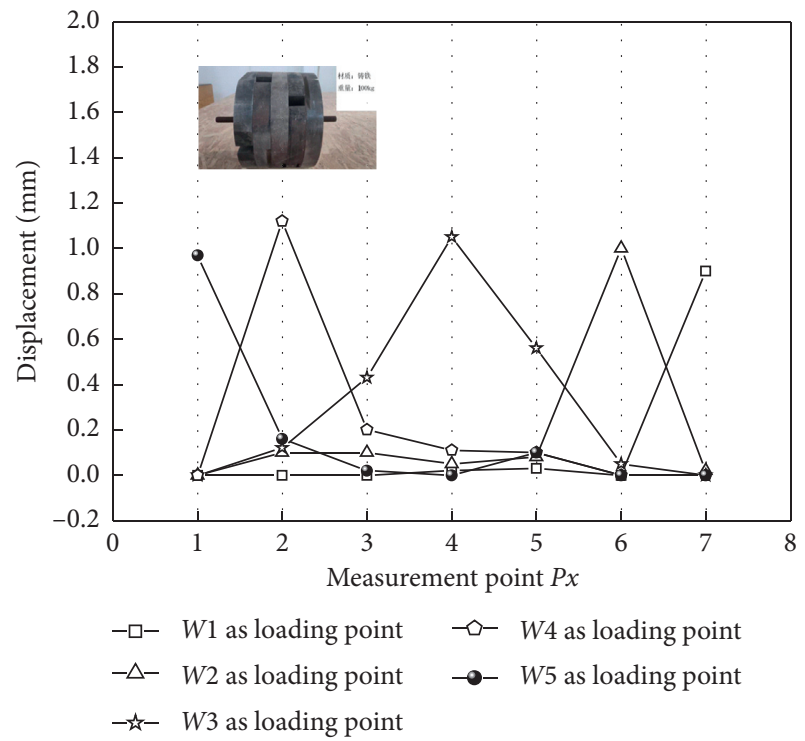

FIGURE 12: Experimental results of the floor deflection for loading on different points $(W)$.

the joists is flexible and results in larger deformation than that of the model II which only considers the flexible metal plate connections. Method III provides the best overall accuracy, followed by method II and method I.

\subsection{Experimental and Numerical Analysis of Vibration Frequencies and Modes}

4.2.1. Vibration Mode and Frequency Testing. The modal frequencies and shapes of the floor system were obtained by the dynamic test according to ISO-18324-2016 [42]. Equally distributed node points $7 \times 15=105$ forming a grid were plotted on the floor surface to serve as excitation points, and five accelerometers (INV9828) were used to measure the vibration acceleration of the floor (to measure the high vibration mode, accelerometers were not installed at the center of the floor system), as illustrated in Figure 16.
Figure 17 shows several kinds of equipment used for the vibration performance testing, including the ICP hammer (INV9314), data acquisition instrument, and accelerometer (INV9828). A person sitting on a movable wood frame moved from one side to the other side of the floor and used an instrumented ICP hammer to hammer the floor and created impact excitation. The distribution of the excitation points was displayed in the DASP-V10 Software on the computer screen. The vertical vibration movements of the measured points were transformed into electrical signals and continually recorded by the data acquisition, and the electrical signals were processed based on fast Fourier transform (FFT) to obtain the frequency response function (FRF). The modal frequencies, shapes, and damping ratios of the tested wood truss joist floor were extracted from the FRF.

\subsubsection{Comparison of the Measured and Modeled Vibration} Mode and Frequencies. Laboratory model testing permits the unambiguous description of the floor boundary conditions. It is very difficult to model the actual support conditions of timber floor structures because the floor system is connected to the wall by screws or nails. In this study, the numerical results indicated that the simplification of the fixed support between the edge joists and the walls $(\mathrm{AB} / \mathrm{CD})$ and the simply supported connection between the other joists and the walls $(\mathrm{AD} / \mathrm{BC})$ provided closest vibration modes to those of the experiments. The modeling results of three modeling methods are consistent with the tested results for the first three-order mode shapes, illustrated in Figure 18. Vertical vibration throughout the floor is observed in the first-order mode. Opposite vibrations in the two parts in the width direction (perpendicular to the joist) were exhibited in the second-order mode, whereas fluctuations for three parts in the width direction were shown in the third-order mode.

Table 5 lists the details of the first three-order frequencies obtained from the experiment and the different numerical models. As to serviceability design, the fundamental frequency of a timberfloor in residential buildings is required to be larger 


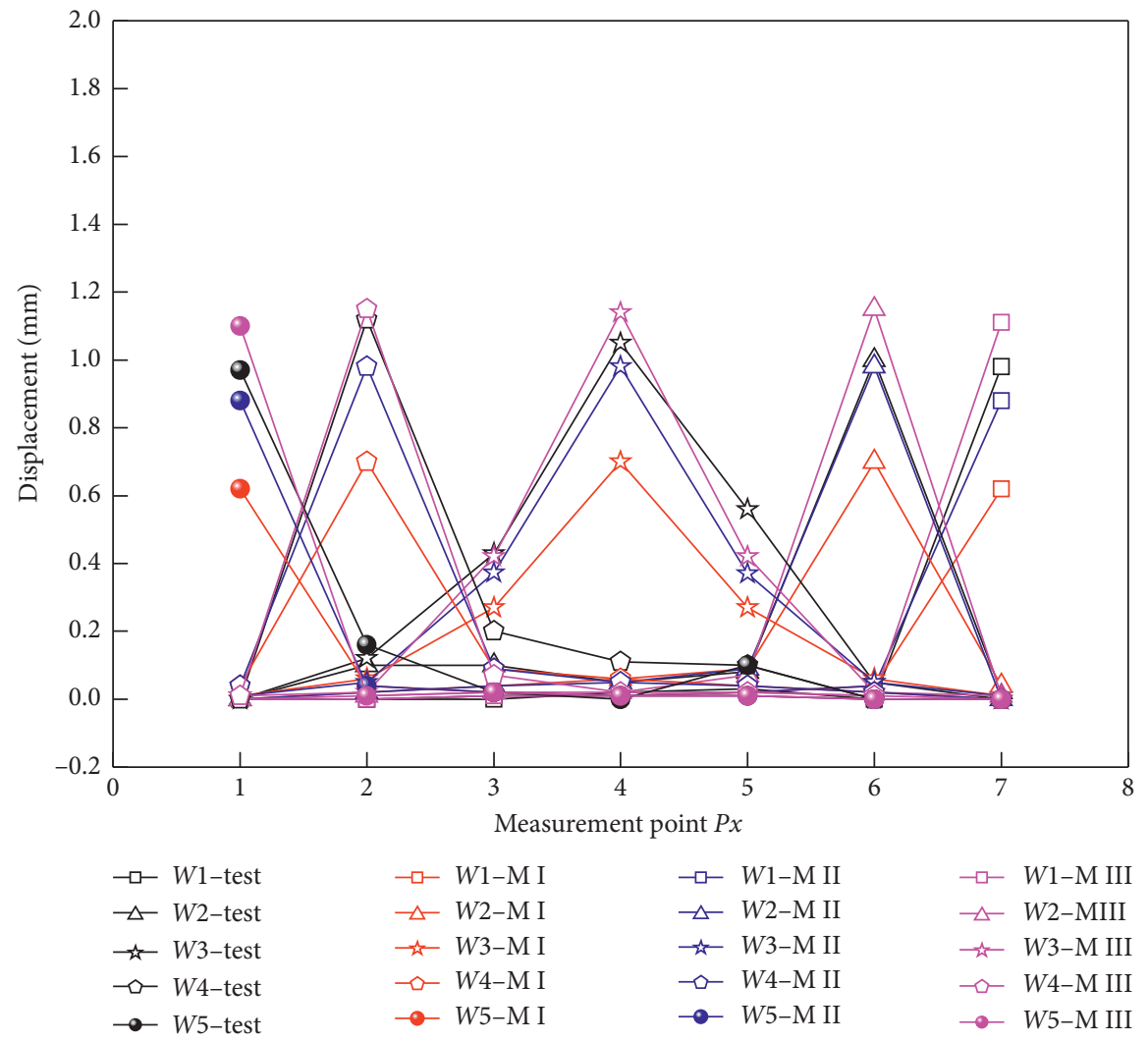

FIgURE 13: Experimental and model results of the floor deflection for loading on different points $(W)$.

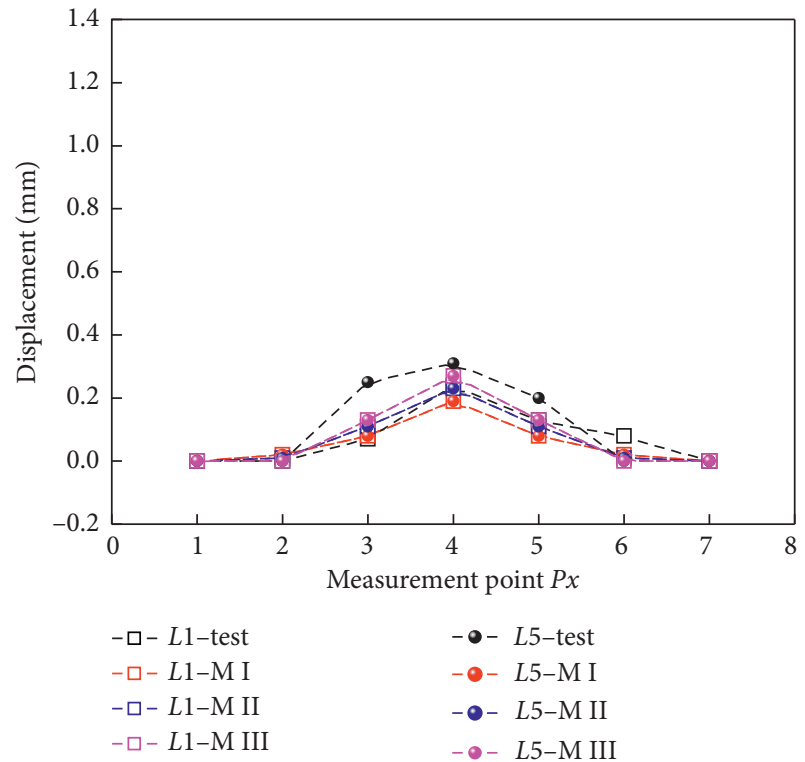

FIGURE 14: Experimental and model results of the floor deflection for loading on $L 1$ and $L 5$.

than $8 \mathrm{~Hz}$. The hammer impact test indicated that the first vertical mode of the vibration had a frequency of $15 \mathrm{~Hz}$.

Methods I/II/III provided different values of the fundamental frequency of the floor. Method I, which ignores the effects of the flexible connections, provided the highest fundamental natural frequency $(20.12 \mathrm{~Hz})$ with great

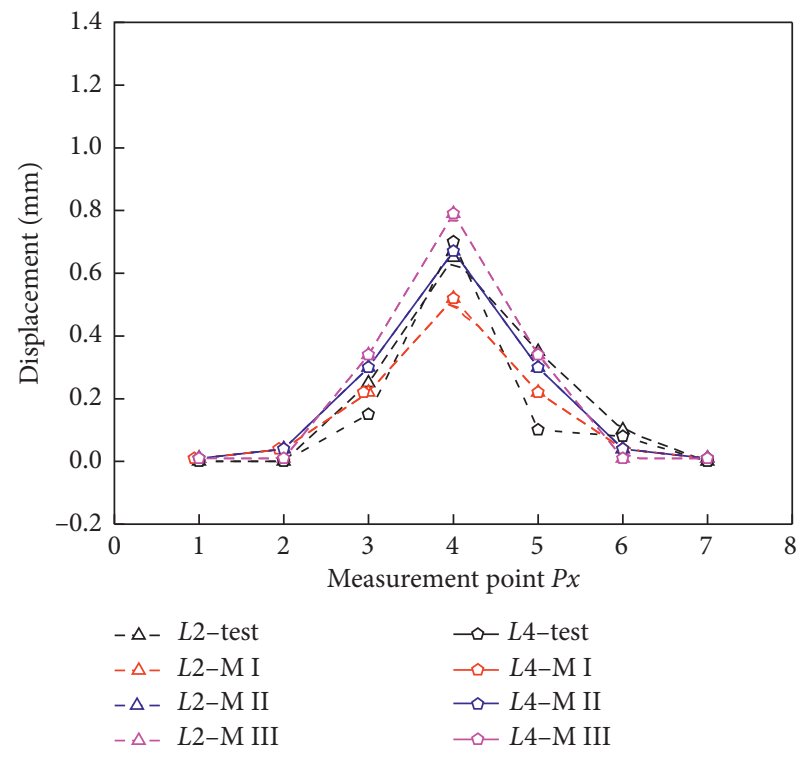

FIGURE 15: Experimental and model results of the floor deflection for loading on $L 2$ and $L 4$.

deviation up to $34.3 \%$. Method II only considers the flexible characteristics of the metal plate connections, which resulted in a slight overestimation of the vibration stiffness of the floor and a high value of the fundamental frequency $(17.73 \mathrm{~Hz})$ with the difference of $18.2 \%$. Method III $(16.9 \mathrm{~Hz})$ with small difference of $12.7 \%$ was closest to the results of the experiment 


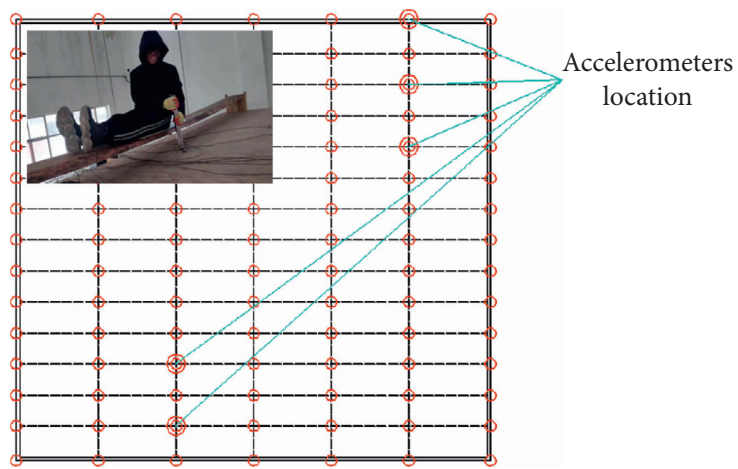

FIgURE 16: Distribution of excitation points.

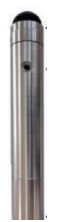

(a)

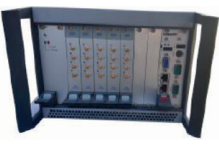

(b)

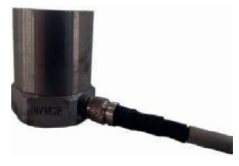

(c)

FIgURE 17: Equipment for vibration performance tests. (a) ICP hammer (INV9314). (b) Data acquisition instrument. (c) Accelerometer (INV9828).
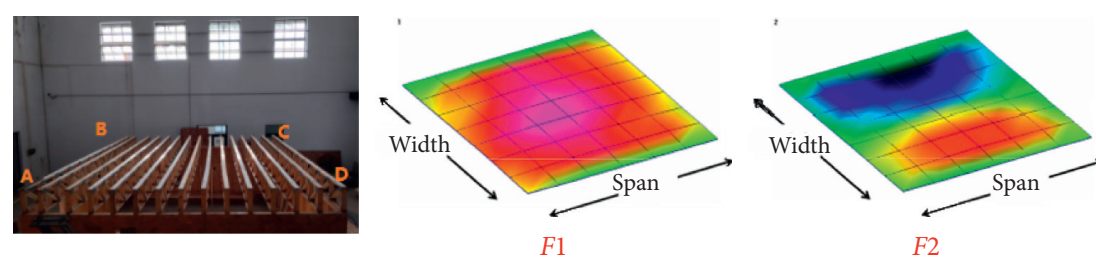

(a)
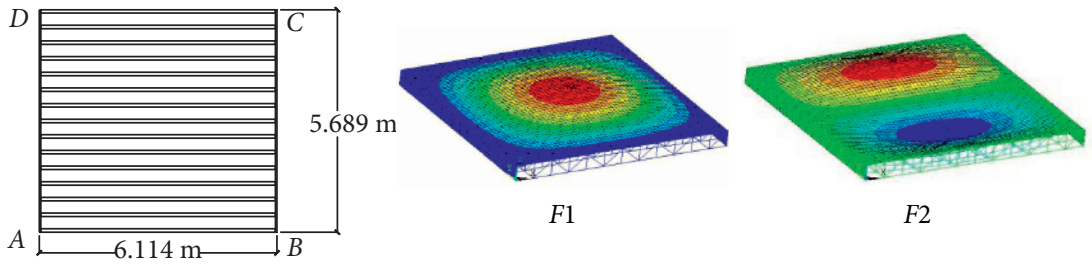

(b)
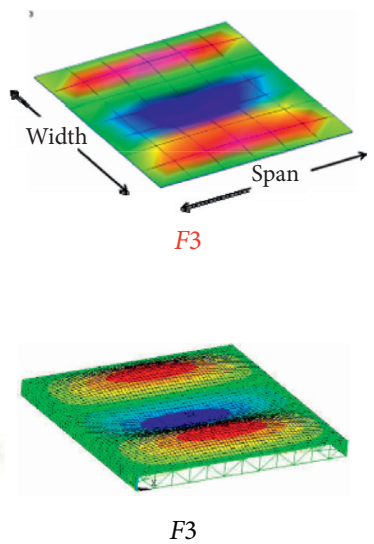

F3

FIGURE 18: First three mode shapes obtained from the experiment (a) and the models I/II/III (b).

because the method considers the flexible characteristics of the metal plate connections of the joists and the nailed/ screwed connections of the sheath to the joist; and the linearelastic stiffness of the floor was simulated. However, the modeling results of the frequency were slightly higher than the experimental results. The reason for the error may be that the fabricated wood truss joist floor had a gap in the connection and there was some variability of the natural wood materials and simplification boundary of numerical models.

Method III also provided good agreement with the second-order frequency $(17.7 \mathrm{~Hz})$ with the difference of less than $1 \%$ versus the tested frequency $(17.8 \mathrm{~Hz})$. As to the fluctuations for three parts in the width direction, method III predicted that the vibration mode occurred at the third-order frequency of $18 \mathrm{~Hz}$ and the sixteenth-order frequency of $20.85 \mathrm{~Hz}$. There are many local mode occurrences at the frequency intervals between $18 \mathrm{~Hz}$ and $20.85 \mathrm{~Hz}$. In the laboratory test, the thirdorder frequency of $21 \mathrm{~Hz}$ was provided, which is close to the modeling sixteenth-order frequency $(20.85 \mathrm{~Hz})$. There are some differences between the modeled and the tested thirdorder frequency. The test may miss the vibration modes at tiny frequency intervals between $18 \mathrm{~Hz}$ and $19 \mathrm{~Hz}$.

Damping is an intrinsic structural property and represents the ability of the floor system to absorb and dissipate vibrational energy. Damping cannot be calculated but is typically determined by a test. Based on the average measured 
TABLE 5: Fundamental frequencies obtained from the experiment and the models.

\begin{tabular}{|c|c|c|c|c|c|c|c|c|}
\hline Method & \multicolumn{2}{|c|}{ Type } & $F 1(\mathrm{~Hz})$ & $\xi 1(\%)$ & $F 2(\mathrm{~Hz})$ & $\xi 2(\%)$ & $F 3(\mathrm{~Hz})$ & $\xi 3(\%)$ \\
\hline Measurement & \multicolumn{2}{|c|}{ Experimental data } & 15 & 7.0 & 17.8 & 7.3 & 21.0 & 5.5 \\
\hline \multirow{3}{*}{ Numerical models } & Method I & $\begin{array}{c}\text { Value } \\
\text { Difference }\end{array}$ & $\begin{array}{c}20.12 \\
34.3 \%\end{array}$ & - & $\begin{array}{l}22.52 \\
26.5 \%\end{array}$ & - & $\begin{array}{c}24.08 \\
14.7 \%\end{array}$ & - \\
\hline & Method II & $\begin{array}{c}\text { Value } \\
\text { Difference }\end{array}$ & $\begin{array}{l}17.73 \\
18.2 \%\end{array}$ & - & $\begin{array}{l}18.96 \\
6.5 \%\end{array}$ & - & $\begin{array}{l}19.56 \\
6.8 \%\end{array}$ & - \\
\hline & Method III & $\begin{array}{c}\text { Value } \\
\text { Difference }\end{array}$ & $\begin{array}{c}16.90 \\
12.7 \%\end{array}$ & - & $\begin{array}{c}17.7 \\
0.56 \%\end{array}$ & - & $\begin{array}{c}18 / 20.85(F 6) \\
14 \% / 0.7 \%\end{array}$ & - \\
\hline
\end{tabular}

damping ratios for the first three-order modes, a damping ratio of $6.6 \%$ or simply $5 \%$ is used for the vibration analysis of the wood truss joist floors in the subsequent analysis.

4.3. Numerical Prediction of Vibration Induced by Walking. Excessive vibration of a lightweight floor structure may occur when a person walks on the floor, resulting in a vibration serviceability problem. In this part, we discuss vibration performance of the floor obtained from different modeling methods. The responses of different floor models to a walking load were compared to optimize the model for a future vibration serviceability study.

4.3.1. The Human Walking Model and Paths. We used the single-step load function proposed by Chen and Li [43, 44]; a person with a mass of $90 \mathrm{~kg}$ and $2 \mathrm{~Hz}$ walking frequency was considered, and a stride length of $600 \mathrm{~mm}$ and 5\% damping were assumed, in Figure 19.

$$
\begin{aligned}
F_{S}(t) & =m g \sum_{n=1}^{5} A_{n} \sin \left(\frac{\pi n}{T_{s}} t\right), \\
T_{S} & =\frac{1}{0.76 f_{s}}, \\
T & \in\left[0, T_{s}\right], \\
A_{1} & = \begin{cases}-0.0698 f_{S}+1.211, & 1.6 \mathrm{~Hz} \leq f_{S} \leq 2.32 \mathrm{~Hz}, \\
-0.1784 f_{S}+1.463, & 2.32 \mathrm{~Hz}<f_{S} \leq 2.4 \mathrm{~Hz},\end{cases} \\
A_{2} & = \begin{cases}0.1052 f_{S}-0.1284, & 1.6 \mathrm{~Hz} \leq f_{S} \leq 2.32 \mathrm{~Hz}, \\
-0.4716 f_{S}+1.210, & 2.32 \mathrm{~Hz}<f_{S} \leq 2.4 \mathrm{~Hz},\end{cases} \\
A_{3} & = \begin{cases}0.3002 f_{S}-0.1534, & 1.6 \mathrm{~Hz} \leq f_{S} \leq 2.32 \mathrm{~Hz}, \\
-0.0118 f_{S}+0.5703, & 2.32 \mathrm{~Hz}<f_{S} \leq 2.4 \mathrm{~Hz},\end{cases} \\
A_{4} & = \begin{cases}0.0416 f_{S}-0.0288, & 1.6 \mathrm{~Hz} \leq f_{S} \leq 2.32 \mathrm{~Hz}, \\
-0.2600 f_{S}+0.6711, & 2.32 \mathrm{~Hz}<f_{S} \leq 2.4 \mathrm{~Hz},\end{cases} \\
A_{5} & = \begin{cases}-0.0275 f_{S}+0.0608, & 1.6 \mathrm{~Hz} \leq f_{S} \leq 2.32 \mathrm{~Hz}, \\
0.0906 f_{S}-0.2132, & 2.32 \mathrm{~Hz}<f_{S} \leq 2.4 \mathrm{~Hz},\end{cases}
\end{aligned}
$$

where $F_{s}(t)$ represents the single footfall force, $A_{n}$ stands for the load factors of each order, $T_{s}$ is the period of a single

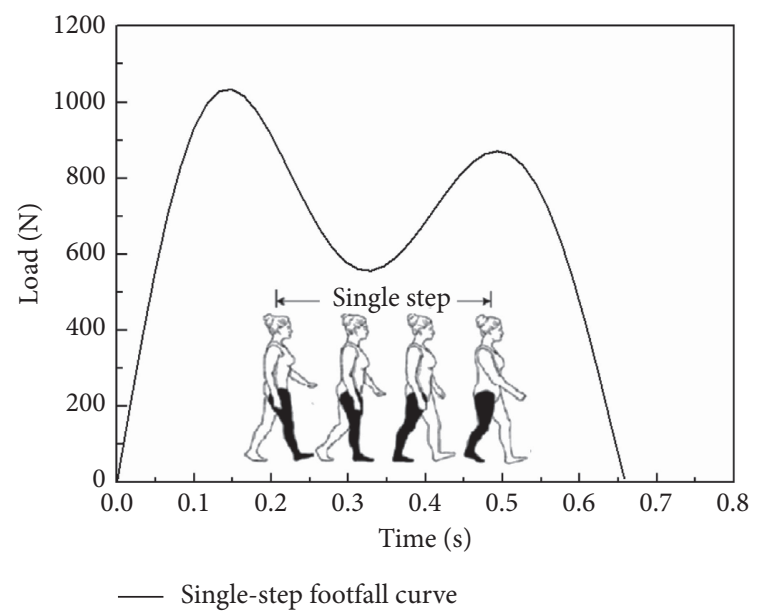

Figure 19: Single footfall force.

footfall, $f_{s}$ represents the walking frequency, and $m$ is the pedestrian mass.

The cases of a person walking perpendicular to the joist direction (Figure 20) and parallel to the joist direction (Figure 21) were simulated. Owing to the stiffness inhomogeneity and differences of the wood joisted floor, the deformation and acceleration responses were predicted and investigated at two points near the floor center. The monitoring point $A$ is located on the sheathing at the center of the middle joist, and the monitoring point $B$ is located at $100 \mathrm{~mm}$ in the vertical direction from $A$, as shown in Figures 20-21. The use of different measuring points was required to obtain an accurate assessment of the dynamic response of the wood truss joist floor because there may be installment errors of the acceleration transducer in the laboratory test.

4.3.2. Comparison of the Vibration Responses of the Different Floor Models. The vertical deformation-time curves at points $A$ and $B$ for the simulation of a person walking perpendicular to the joists ( $W$ line) are presented in Figure 22. It was found that method III provided larger displacement values than methods II and I, and the differences between the methods were greater at point $B$ than those at point $A$. The maximum vibration deflection occurred at the center of the floor, and the walking perpendicular to the joists at the far place produced little influence on vibration deformation at the floor center, where the curves showed almost horizontal line for a relatively long time period. There 


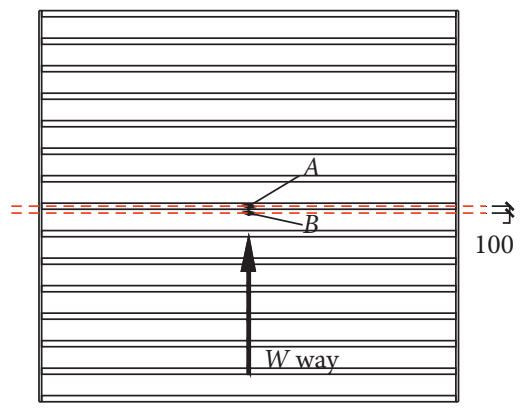

FIgURE 20: Walking perpendicular to the joist direction ( $W$ line).

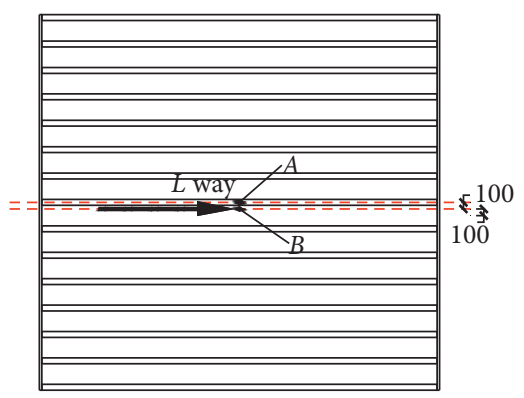

FIGURE 21: Walking parallel to the joist direction ( $L$ line).

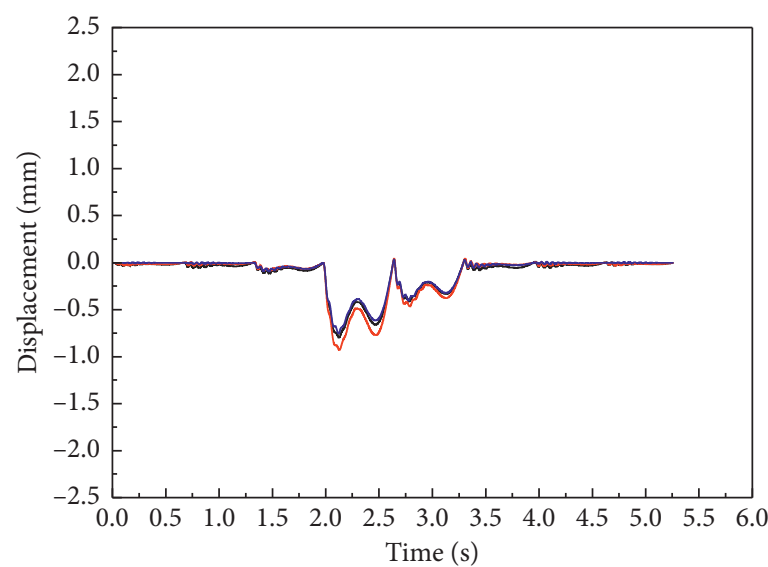

Walking along $W$ line

- Vertical displacement at $A$ point (M II)

— Vertical displacement at $A$ point (M III)

— Vertical displacement at $A$ point (M I)

(a)

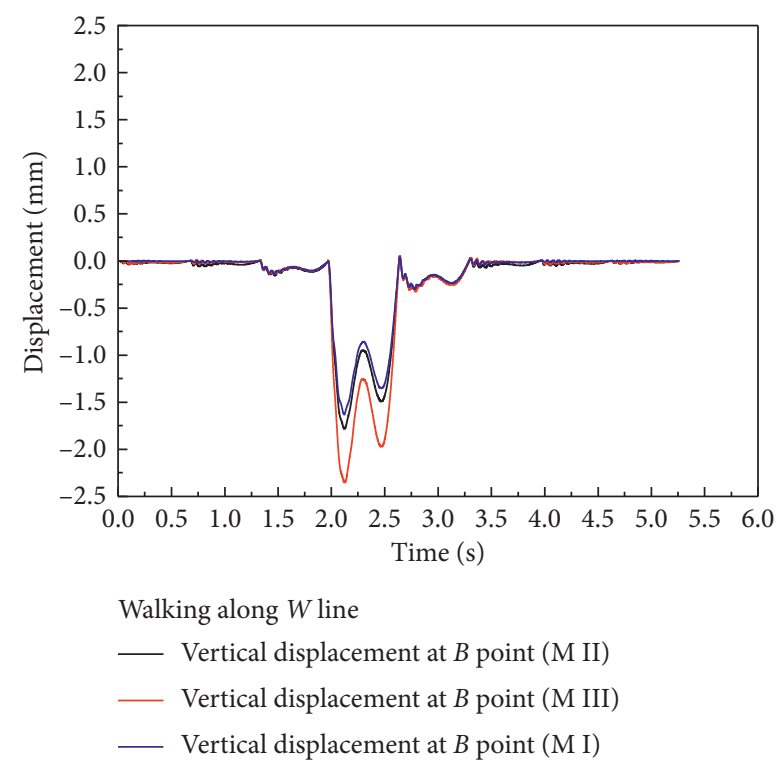

(b)

Figure 22: Prediction of the displacement response at points (a) $A$ and (b) $B$ when walking perpendicular to the joists ( $W$ line).

were significant differences in the modeling results for the three methods at the peak; low stiffness was observed at point $B$, and the peak for method III was $2.3 \mathrm{~mm}$, whereas that of method II was $1.8 \mathrm{~mm}$ and method I was about $1.6 \mathrm{~mm}$. The reason is that the sheathing-to-joist screwed connection has linear-elastic stiffness, resulting in larger vibration deflection than the model that only considers the metal plate connection, especially for the vibration between the joists. Without consideration of elastic stiffness of flexible connections, method I greatly underestimated the vibration amplitude and may lead to high errors.

The vibration acceleration-time curves at points $A$ and $B$ for the simulation of a person walking perpendicular to the joists ( $W$ line) are shown in Figure 23. The acceleration was larger at $B$ than at $A$ (about $7.58 \mathrm{~m} / \mathrm{s}^{-2}$ at $B$ and $1.45 \mathrm{~m} / \mathrm{s}^{-2}$ at $A$ for method II; $9 \mathrm{~m} / \mathrm{s}^{-2}$ at $B$ and $1.62 \mathrm{~m} / \mathrm{s}^{-2}$ at $A$ for method III; $3.71 \mathrm{~m} / \mathrm{s}^{-2}$ at $B$ and $1.34 \mathrm{~m} / \mathrm{s}^{-2}$ at $A$ for method I). That is because the acceleration is higher for the slender place 


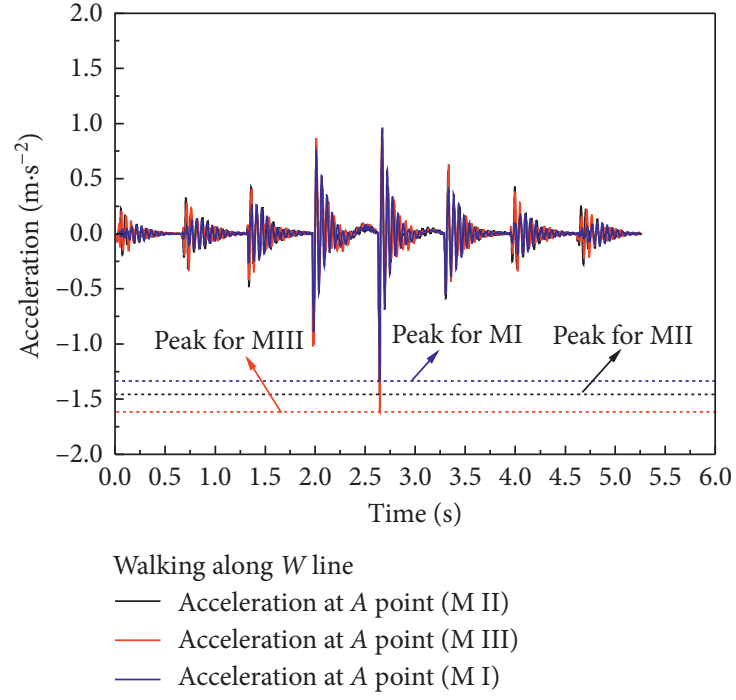

(a)

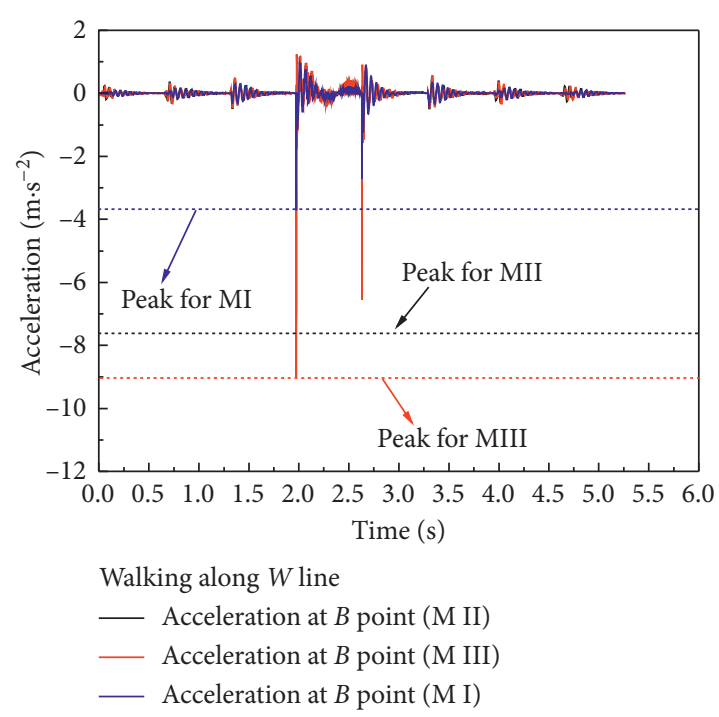

(b)

FIgURE 23: Prediction of the acceleration response at points (a) $A$ and (b) $B$ when walking perpendicular to the joists ( $W$ line).

(between the joists). Three models resulted in the peak acceleration at $2.6 \mathrm{~s}$ at $A$ and $2 \mathrm{~s}$ at $B$.

Table 6 lists the peak acceleration and displacement at $A$ and $B$ for methods I, II, and III. Method III was used as the reference method for calculating the difference. At point $A$, method II, which only considers the linear-elastic characteristics of the metal plate connections, resulted in an underestimation of the peak acceleration (90\%) and the peak displacement $(86 \%)$. The simplification of pinned connections for metal plate connections and rigid connections for sheathing-to-joist connections from method I directly results in large underestimation (83\% at the peak acceleration and $81 \%$ at the peak displacement). At point $B$, method II provided an underestimation of the peak acceleration (84\%) and the peak displacement (76\%); method I lead to large deviation at the peak acceleration (41\%) and the peak displacement $(70 \%)$. It is concluded that the linear-elastic characteristics of the metal plate connections directly affect the dynamic response of wood truss joist floors; meanwhile, the linear-elastic features of the nailed/screwed connections to the sheathing cannot be neglected in a dynamic analysis; the effect is greater between the joists than on the joist. The flexible characteristics of connections are more susceptible to great vibration response.

The vibration responses of the floor at $A$ and $B$ when simulating a person walking parallel to the joist (at a vertical distance of $100 \mathrm{~mm}$ between the $L$ line and the middle joist) are shown in Figure 24. This case is considered because a person may not always walk on the middle joist. Although the force of the footfall is on the sheathing and not on the joist, the load is transferred to the nearest joist (the middle joist) and causes vibration of the entire joist. It was found that method III provided larger fluctuations in the displacement than method II and method I produced the lowest fluctuation. Since A was located on the sheathing and just on the joist, there were slight differences between method I, method II, and method III; the peak displacement was $0.96 \mathrm{~mm}$ for method II, $1.1 \mathrm{~mm}$ for method III, and $0.91 \mathrm{~mm}$ for method I. At $B$, the peak displacement was $2.02 \mathrm{~mm}$ for method III, $1.5 \mathrm{~mm}$ for method II, and $1.34 \mathrm{~mm}$ for method I. Because point $B$ was located on the sheathing between the joists, the displacement was larger because of the linear-elastic nailed connection.

Figure 25 shows the acceleration response at $A$ and $B$ when simulating a person walking along the $L$ line with eight footfalls. The load was transferred to the nearest joist (which is the center joist) and excited the vibration of the center of the joist, with a peak acceleration of more than $1 \mathrm{~m} / \mathrm{s}^{-2}$ at the start. At $A$, method I provided the lowest peak acceleration $\left(1.73 \mathrm{~m} / \mathrm{s}^{-2}\right)$ and method II resulted in lower peak acceleration $\left(1.87 \mathrm{~m} / \mathrm{s}^{-2}\right)$ than method III $\left(2.13 \mathrm{~m} / \mathrm{s}^{-2}\right)$. Since $B$ was on the sheathing and not on the joist, three models exhibited relatively large differences in the acceleration, with a peak acceleration of $4.7 \mathrm{~m} / \mathrm{s}^{-2}$ for method II, $6.44 \mathrm{~m} / \mathrm{s}^{-2}$ for method III, and $2.42 \mathrm{~m} / \mathrm{s}^{-2}$ for method I.

Table 7 summarizes the peak acceleration and displacement at $A$ and $B$ for methods I, II, and III; method III was used as the reference method for calculating the difference. Method II resulted in an underestimation of the peak acceleration (88\%) and peak displacement (87\%) at $A$; method I led to greater underestimations of peak acceleration $(81 \%)$ and peak displacement (82\%). At $B$ for peak acceleration, the underestimations of $73 \%$ for method II and $38 \%$ for method I were demonstrated; for peak displacement, the underestimations of $74 \%$ for method II and $38 \%$ for method I were given. Thus, in human-induced vibration analysis, the linear-elastic stiffness of the sheathing-to-joist nailed/screwed connections and metal plate connections cannot be ignored. Method III is the preferred method for floor vibration analysis because all factors are considered, including the linear-elastic stiffness of the metal plate connections of the joists and the sheathing-to-joist connections. 
TABLE 6: Summary of modeling results for a person walking along the $W$ line.

\begin{tabular}{|c|c|c|c|c|c|c|c|c|c|}
\hline \multirow{2}{*}{\multicolumn{2}{|c|}{$\begin{array}{l}\text { Monitoring type } \\
\text { Monitoring point }\end{array}$}} & \multicolumn{2}{|c|}{$\begin{array}{c}\text { Peak acceleration } \\
\left(\mathrm{m} \cdot \mathrm{s}^{-2}\right)\end{array}$} & \multicolumn{2}{|c|}{$\begin{array}{l}\text { Peak displacement } \\
(\mathrm{mm})\end{array}$} & \multicolumn{2}{|c|}{$\begin{array}{c}\text { Peak acceleration } \\
\left(\mathrm{m} \cdot \mathrm{s}^{-2}\right)\end{array}$} & \multicolumn{2}{|c|}{$\begin{array}{l}\text { Peak displacement } \\
(\mathrm{mm})\end{array}$} \\
\hline & & A & Ratio (\%) & A & Ratio (\%) & $B$ & Ratio (\%) & $B$ & Ratio (\%) \\
\hline \multirow{3}{*}{$W$ line } & Method I & 1.34 & 83 & 0.75 & 81 & 3.71 & 41 & 1.63 & 70 \\
\hline & Method II & 1.45 & 90 & 0.80 & 86 & 7.58 & 84 & 1.79 & 76 \\
\hline & Method III & 1.62 & - & 0.93 & - & 9.01 & - & 2.35 & - \\
\hline
\end{tabular}

Note. Method III is the reference for calculating the difference.

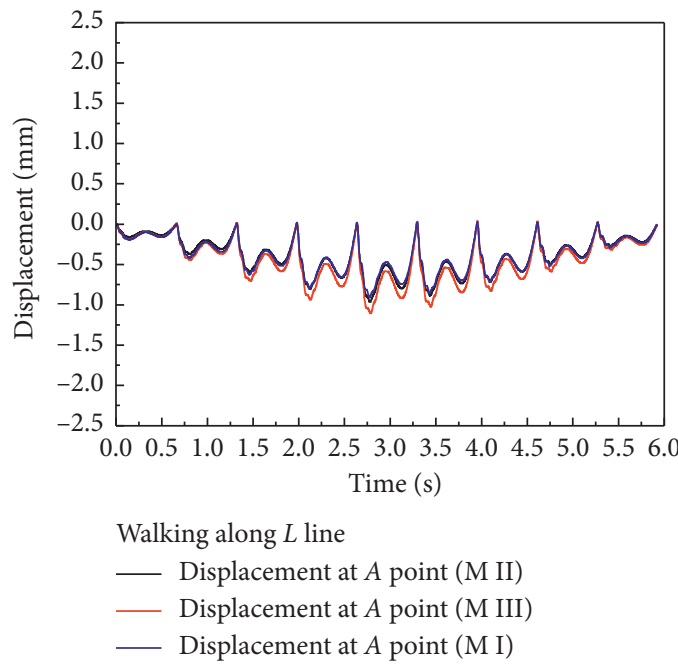

(a)

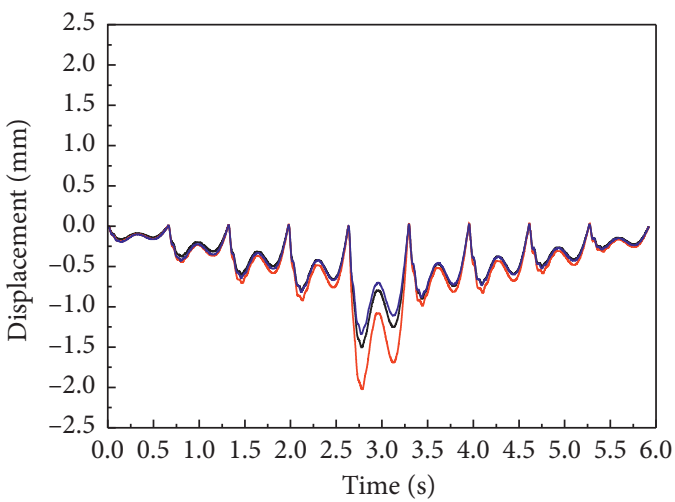

Walking along $L$ line

- Displacement at $B$ point (M II)

Displacement at $B$ point (M III)

- Displacement at $B$ point (M I)

(b)

Figure 24: Prediction of the displacement response at points (a) $A$ and (b) $B$ when walking parallel to the joists ( $L$ line).

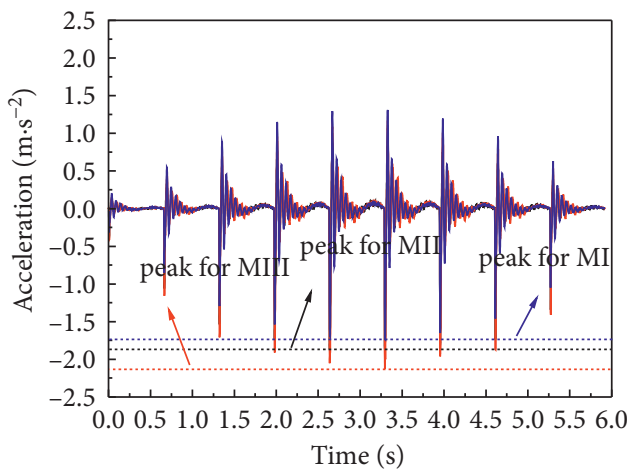

Walking along $L 1$ line

- Acceleration at $A$ point (M II)

- Acceleration at $A$ point (M III)

- Acceleration at $A$ point (M I)

(a)

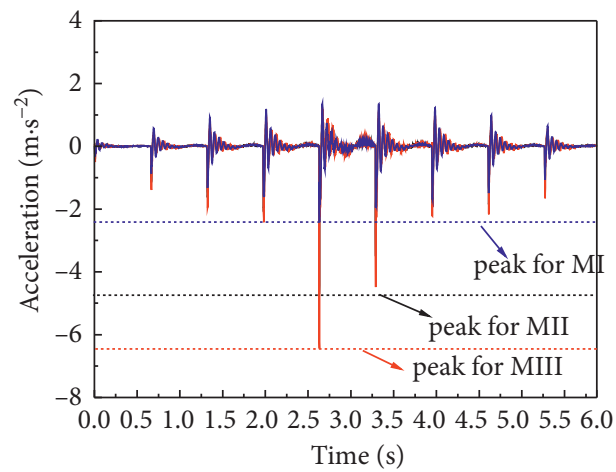

Walking along $L 1$ line

- Acceleration at $B$ point (M II)

- Acceleration at $B$ point (M III)

— Acceleration at $B$ point (M I)

(b)

Figure 25: Predication of the acceleration response at points (a) $A$ and (b) $B$ when walking parallel to the joists ( $L$ line).

TABLE 7: Summary of modeling results for a person walking along the $L$ line.

\begin{tabular}{lcccccccc}
\hline Monitoring type & \multicolumn{2}{c}{$\begin{array}{c}\text { Peak acceleration } \\
\left(\mathrm{m} \cdot \mathrm{s}^{-2}\right)\end{array}$} & \multicolumn{2}{c}{$\begin{array}{c}\text { Peak displacement } \\
(\mathrm{mm})\end{array}$} & \multicolumn{2}{c}{$\begin{array}{c}\text { Peak acceleration } \\
\left(\mathrm{m} \cdot \mathrm{s}^{-2}\right)\end{array}$} & \multicolumn{2}{c}{$\begin{array}{c}\text { Peak displacement } \\
(\mathrm{mm})\end{array}$} \\
Monitoring point & $A$ & Ratio (\%) & $A$ & Ratio (\%) & $B$ & Ratio (\%) & $B$ & Ratio (\%) \\
\hline \multirow{2}{*}{ L line } & Method I & 1.73 & 81 & 0.91 & 82 & 2.42 & 38 & 1.34 \\
& Method II & 1.87 & 88 & 0.96 & 87 & 4.71 & 73 & 1.50 \\
& Method III & 2.13 & - & 1.11 & - & 6.44 & - & 2.02 \\
\hline
\end{tabular}

Note. Method III is the reference for calculating the difference. 


\section{Conclusion}

Numerical simulations and laboratory tests were conducted to investigate vibration performances of wood truss joist floors. The three floor models were developed to predict the vibration modes/frequencies, static response under a concentrated load, and human-induced vibration response of a full-size floor. The response of the floor models was compared with the tested results to optimize the model for a future vibration serviceability study.

Method I neglecting the flexible connections will result in the obvious underestimations of predictions of static deformation and vibration acceleration and deformation of the wood truss joist floor. Neglecting the flexible characteristics of the sheathing-to-joist fasteners connections (method II) may result in distinct underestimation of prediction of vibration response, especially at the slender place of the wood truss joist floor. The flexible metal plate connections have a significant influence on the vibration performance of wood truss joist floors, while the flexible characteristics of the sheathing-to-joist nailed/screwed connections contribute nonnegligible amount on the vibration performance.

For method III, metal plate connection is simplified by orthogonal springs between the composite force node for multiweb members and the chord node; sheathing-to-joist connection is also simplified by orthogonal springs to quantify the elastic stiffness. It is valid to predict a series of static response under concentrated loading, vibration frequencies, and modes of the full-size floor tests. It also considers all factors and provides the best performance for the vibration prediction of the wood truss joist floor.

For wood truss joist floors, the vibration induced by walking more easily affects the deflection of the adjacent joist; however, the deformation influence on other joists that are three spaces away is minimal. However, different walking ways produced steep vibration acceleration fluctuations at the floor center for a relatively long time period. The deformation and acceleration are much higher for the more slender place (between the joists) compared to the sheathing on the joists. For the future study of vibration performance of the wood truss joist floor, comprehensive assessments are needed for the place on the joist and the place between the joists.

In general, this study presents a feasible and accurate numerical method to predict the vibration performance of wood truss joist floor systems. Further research will be conducted on the effect of strong backs, thickness of subfloor, and other geometric configurations of floors on the vibration performance of the wood truss joist floor system so as to improve the predicting method. The results will be reported when available.

\section{Data Availability}

The data in this paper are given in the tables and figures within the manuscript.

\section{Conflicts of Interest}

The authors declare no conflicts of interest.

\section{Acknowledgments}

This project was supported by the National Natural Science Foundation of China (31770603 and 52008011) and Science and Technology Project of Beijing Municipal Education Commission (KM201910005019).

\section{References}

[1] American Plywood Association (Apa), I-joist Construction Details, Form No. EWSD710A, American Plywood Association (Apa), Tacoma, WA, US, 2004.

[2] G. Chen, C. Tan, W. Yang et al., "Wood I-joists with web holes and flange notches: a literature review," Journal of Building Engineering, vol. 38, Article ID 102224, 2021.

[3] B. M. Basaglia, "Dynamic behaviour of long-spantimber ribbed-deck floors," Ph.D. Thesis, university of Technology, Sydney, Australia, 2019.

[4] S. Ohlsson, Floor Vibration and Human Discomfort, Ph.D. Thesis, Chalmers University of Technology, Göteborg, Sweden, 1982.

[5] I. Smith and Y. HChui, "Design of lightweight wooden floors to avoid human discomfort," Canadian Journal of Civil Engineering, vol. 5, pp. 254-261, 1987.

[6] J. R. Johnson, "Vibration acceptability in wood floor systems," Master's Thesis, Virginia Polytechnic Institute and State University, Blacksburg, VA, USA, 1994.

[7] J. D. Dolan, T. M. Murray, J. R. Johnson, D. Runte, and B. C. Shue, "Preventing annoying wood floor vibrations," Journal of Structural Engineering, vol. 125, no. 1, pp. 19-24, 1999.

[8] M. M. Patrick, "Another proposed rule of thumb for controlling floor vibration," Wood Design Focus, p. 3, 1997.

[9] European Committee for Standardization (CEN), Eurocode5: Design of Timber Structures. Part 1-1: General Common Rules and Rules for Buildings, European Committee for Standardization (CEN), Brussels, Belgium, 2004.

[10] A. M. Khokhar, "Influence of lateral element stiffness on performance of wooden floors," MS Thesis, University of New Brunswick, Fredericton, Canada, 2006.

[11] J. Weckendorf, Dynamic Response of Structural Timber Flooring Systems, Ph.D. Thesis, Edinburgh Napier University, Edinburgh SC, UK, 2009.

[12] J. Weckendorf, T. Toratti, I. Smith, and T. Tannert, "Vibration serviceability performance of timber floors," European Journal of Wood and Wood Products, vol. 74, no. 3, pp. 353-367, 2016.

[13] B. Zhang, A. Kermani, and T. Fillingham, "Vibrational performance of timber floors constructed with metal web joists," Engineering Structures, vol. 56, pp. 1321-1334, 2013.

[14] B. Zhang, A. Kermani, and T. Fillingham, "Vibrations of metal web joist timber floors with strongbacks," Proceedings of the Institution of Civil Engineers-Structures and Buildings, vol. 169 , no. 8 , pp. 549-562, 2016. 
[15] B. SZhang, Parametric Study on the Design of Timber Floor Joists to Eurocode 5 and National Annex, BSI, London, UK, 2004.

[16] B. S. Zhang, A. Bahadori, and A. Kermani, Influence of EC5 and the UK National Annex on the Design of Timber Flooring Systems Built with Multi-Webbed Engineered Joists and Solid Timber Joists, BSI, London, UK, 2005.

[17] E. S. Bernard, "Dynamic serviceability in lightweight engineered timber floors," Journal of Structural Engineering, vol. 134, no. 2, pp. 258-268, 2008.

[18] K. Jarnero, "Vibrations in timber floors: dynamic properties and human perception," Ph.D. Thesis, Linnaeus University, Växjö, Sweden, 2014.

[19] K. Jarnerö, A. Brandt, and A. Olsson, "Vibration properties of a timber floor assessed in laboratory and during construction," Engineering Structures, vol. 82, pp. 44-54, 2015.

[20] Y. Ding, Y. Zhang, Z. Wang et al., "Vibration test and comfort analysis of environmental and impact excitation for wooden floor structure," Bioresources, vol. 14, no. 4, pp. 8212-8234, 2020.

[21] L. J. Hu, "Prediction of vibration responses of ribbed plates by modal synthesis," Ph.D. Thesis, University of New Brunswick, Fredericton, Canada, 1992.

[22] J. Weckendorf, B. Zhang, A. Kermani et al., "Finite element modeling of i-joist timber flooring systems to predict modal frequencies, modal shapes and static point load deflections," in Proceedings of the World Conference On Timber Engineering (WCTE), Riva del Garda, Italy, June 2010.

[23] I. Glisovic and B. Stevanovic, "Vibrational behavior of timber floors," in Proceedings of the World Conference On Timber Engineering (WCTE), Riva del Garda, Italy, June 2010.

[24] J. WPark, T. H. Ha, and H. JKim, "Finite element modeling and experimental verification of lightweight steel floor vibration," Journal of Vibroengineering, vol. 18, no. 3, pp. 1435-1443, 2016.

[25] S. Zhang, L. Xu, and J. Qin, "Vibration of lightweight steel floor systems with occupants: m," Engineering Structures, vol. 147, pp. 652-665, 2017.

[26] M. Setareh, "Vibration serviceability of a building floor structure. I: dynamic testing and computer modeling," Journal of Performance of Constructed Facilities, vol. 24, no. 6, pp. 497-507, 2010.

[27] K. C. Barron and J. B. Kim, "Non-linear modeling of the heel joint of metal plate connected roof trusses," in Proceedings of the World Conference on Timber Engineering (WCTE), Whistler, Canada, August 2000.

[28] X. LXu, "Research on bearing capacity of light wood truss," MS thesis, TongjiUniversity, Shanghai, China, 2006.

[29] ASTM. Astm2126, Standard Test Methods for Cyclic(reversed) Load Test for Shear Resistance of walls for Buildings, ASTM, West Conshohocken, PA, US, 2011.

[30] Cen. EN12512, Timber Structures-Test Methods-Cyclic Testing of Joints Made with Mechanical Fasteners, European Committee for Standardization, Brussels, Belgium, 2001.

[31] M. Yasumura and N. Kawai, "Estimating seismic performance of wood-framed structures," in Proceedings of the World Conference on Timber Engineering(WCTE), pp. 564-571, Montreux, Switzerland, August 1998.

[32] Commonwealth Scientific and Industrial Research Organization(CSIRO), Timber Evaluation of Mechanical Joint Systems-Part 3, CSIRO, Melbourne, Australia, 1996.

[33] E. Karacabeyli and A. Ceccotti, "Quasi-static reversed cyclic testing of nailed joints," in Proceedings of the International Council for Building and Research Studies and Documentation
Working Commission W18-Timber Structure, Karlsruhe, Germany, 1996.

[34] Y. Shen, J. Schneider, S. Tesfamariam, S. F. Stiemer, and Z. Chen, "Cyclic behavior of bracket connections for crosslaminated timber (CLT): assessment and comparison of experimental and numerical models studies," Journal of Building Engineering, vol. 39, no. 41, Article ID 102197, 2021.

[35] L. H. Wang, "Experimental investigation on shear behavior of metal plate connected joints in light wood constructions," MS Thesis, Chongqing University, Chongqing, China, 2011.

[36] Y. Kuang, "Experimental investigation on wood joint connected by truss plate of light truss," MS. Thesis, Chongqing University, Chongqing, China, 2011.

[37] H. Ye, "Research on the tension performance of metal plate connected tension splice joint in domestic larch dimension lumber," MS. Thesis, Beijing forestry University, Beijing, China, 2010.

[38] Y. Yang, "Comparative experimental study of the three structural materials metal-plate connection and mechanical model building," MS. Thesis, Beijing forestry University, Beijing, China, 2013.

[39] N. B. CC. National, Building Code of Canada, 2015.

[40] JGJ/T265, Technical Code for Light wood Trusses, 2012.

[41] ASTM, ASTM E73-13.Standard Practice for Static Load Testing of Truss Assembiles, ASTM, West Conshohocken, PA, US, 2013.

[42] Iso18324, Timber Structures-Test Methods-Floor Vibration Performance, International Organization for Standardization, Geneva, Switzerland, 2016.

[43] Y. Chen, "Walking incentive loads pedestrian overpass vibration and vibration reduction research," MS Thesis, University of Tsinghua, Beijing, China, 2007.

[44] Q. Li, "Human-induced stochastic vibration and optimal control for long-span footbridges and floors," MS Thesis, University of Tsinghua, Beijing, China, 2010. 